\title{
Else Hirschberg (1892-1942): the rediscovery of the private and professional life of the first female chemistry graduate at Rostock University in a digitised world
}

Received: 13 June 2017

Accepted: 18 November 2017

Additional information is available at the end of the article.

KEYWORDS: history of chemistry; women's studies; women in science; Jewish chemists; anti-Semitism; Shoah; Germany; German Jews; German civil registration; Prussian Jews
Tim Peppel and Gisela Boeck

Abstract: In preparing for the six-hundredth anniversary of Rostock University, the question arose: who were the first female students at the Institute of Chemistry? With the help of digitised material of enrolments and printed lists of graduations at the beginning of the twentieth century, the first female graduate, Else Hirschberg, was found. This article examines her life, her scientific career and her fate. After outlining the history of women's studies in Germany and the methodological approach taken, particular attention is paid to the ancestry of Else Hirschberg's Jewish family. Detailed information about Else, her family and her maternal and paternal lineage is described. The second part of the article describes Else Hirschberg's academic career and the network she used in her attempts to emigrate from Germany. It is not possible to know the exact reasons for her decision to study chemistry, but an impressive picture of her scientific efforts has been drawn. Facts about her life and that of her family represent the uncountable personal histories and legacies of those Jewish Germans murdered in the Shoah.

\section{Introduction}

\section{Historical background - women in natural sciences}

When you look at photographs depicting the staff and students of the chemical laboratory at Rostock University (see Figure 1) from the beginning of the twentieth century, it is quite obvious that there are no women present.

At that time, female students were rather unusual at German universities and the German Civil Code (Bürgerliches Gesetzbuch) from 1900 characterised the woman's task as that of being a loving, obedient wife and a good mother. ${ }^{1}$ Nevertheless, since the mid 1800 s there had been an intense debate about studies for females (Frauenstudium) in Germany, influenced by the opportunities of women to study abroad. The first major step was taken in 1895, when the Prussian Ministry allowed universities to permit women to attend lectures and seminars at German universities as guest auditors (Gasthörerinnen). Female guest auditors had to apply for admission. This application had to be supported and approved by each professor, each faculty and finally by the Ministry of Education (Kultusministerium) too. (For comparison: in the UK and USA women have given lectures since the 1870s at women's colleges, women have been granted access to Swiss universities since 1868 and have been allowed to undertake doctoral studies since 1874). ${ }^{2}$ Interestingly, a survey by Arthur Kirchhoff (1871-1921) of 126 German lecturers - of which fifteen were natural scientists - showed that most of them approved females as guest auditors but only in exceptional cases. ${ }^{3}$ Baden was the first German state which allowed women to become regular students by enrolment in 1900, with Prussia following in 1908. Mecklenburg was the last German state that allowed females to regularly enter its universities in 1909, gaining academic civil rights (akademische Bürgerrechte) and receiving the so-called große Matrikel. ${ }^{4}$ The number of women who entered the universities as Gasthörerinnen increased rapidly but the proportion of women who studied chemistry was small (about $2 \%$, often in connection with other sciences). ${ }^{5}$ They completed their studies with the so-called association exam (Verbandsexamen) and in some cases with a doctoral examination. 


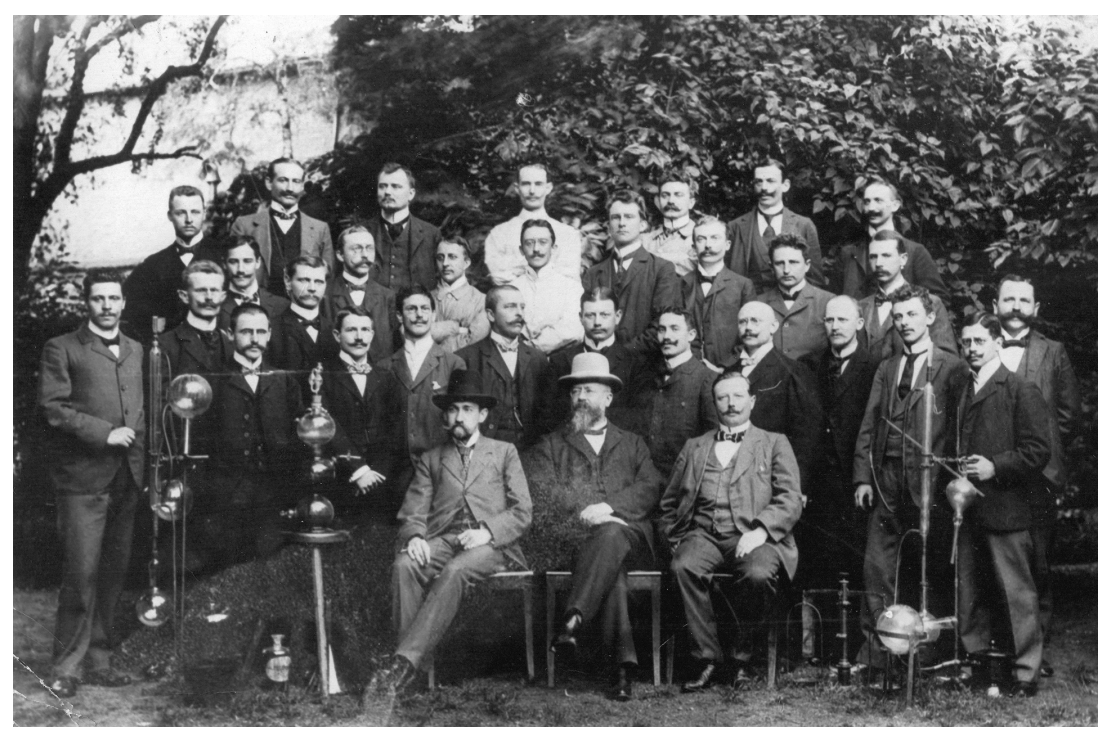

Figure 1. Staff members and students at the chemical laboratory at Rostock University in $1903 .^{6}$

The Verbandsexamen was introduced in 1898 by the Association of Laboratory Directors at German Universities and Colleges (Verband der Laboratoriumsvorstände an Deutschen Hochschulen) which was founded in 1897 to enable comparison of students' qualifications. Chemical studies at universities mainly focused on organic chemistry, and inorganic as well as analytical chemistry became more and more neglected. In contrast, chemical studies at polytechnic schools and technical universities were strictly focused on the requirements of the chemical industry and the curricula were tightly organised.

The first German woman who passed the Verbandsexamen was Clara Immerwahr (1870-1915) in Breslau, Silesia (today Wrocław, Poland), ${ }^{7}$ and she was the first German female ${ }^{8}$ to receive a doctorate in chemistry in 1900. (The first woman who earned a doctorate in chemistry was the Russian, Julia Lermontova (1847-1919).$^{9,10}$ ) The first regular female chemistry student at Rostock University was Anna Müller (born in 1891 in Elberfeld) who enrolled on 29 April 1913. Prior to her studies in Rostock she attended universities in Bonn, Freiburg, and Paris. She left Rostock University only one year later on 4 March 1914 without graduating in chemistry. ${ }^{11}$ She did not pass the pre-doctoral Verbandsexamen or the doctoral examination, either at Rostock or at another German university (no mention of her can be found in the Reports of Laboratory Boards (Berichte der Laboratoriumsvorstände). So the first female student to receive the Verbandsexamen at Rostock was Else Hirschberg (No. 9980), on 25 July 1913 under the supervision of August Michaelis (1847-1916). ${ }^{12}$ She was not a regular student but a Gasthörerin.

\section{Methodology}

Due to the lack of surviving primary sources (Jewish civil registers) after World War II, we investigated the digitised German civil registers that are now accessible for the first time. Civil registration offices were established in Germany on 1 February 1870 in Baden, on 1 October 1874 in Prussia, and on 1 January 1876 in all other territories of the German Empire. There are three different German civil registers, namely for births, marriages, and deaths. Until 1 January 2009, these could only be accessed by direct relatives and it was almost impossible to access and obtain personal information on people who were not related to oneself. On that date, the amended version of the German civil registration law (Personenstandsgesetz) took effect. Since 2009, all registers older than 110 years for births, older than 80 years for marriages, and older than 30 years for deaths have to be transferred to public archives ${ }^{13}$ and hence become accessible not only to family members, but also to the public, including genealogists. Since those older registers are accessible by archive regulations, major genealogy websites have started to digitise the information.

The leading websites offering digitised and searchable German civil registers (as well as Jewish records) are Ancestry.com and FamilySearch. org. For our research, the possibilities of Ancestry.com were investigated and used to compile an extended family tree of Else Hirschberg, which can now be found on that website. This undertaking would have been almost impossible prior to 2009 and the change of the German civil registration law. We also became aware of other digitised resources from archives around the world, such as the Gerda Sainer Collection at the library of the University of Sussex, and the Max Bergmann papers which are accessible electronically via the American Philosophical Society, referred to below. These sources contain especially detailed information on Else Hirschberg's direct ancestors and their descendants, as well as information about her professional life after her dismissal from Rostock University in 1933. The possibilities of digitised resources 
cannot be overestimated and without them this article would not have been possible. (Other institutions which provided additional information can be found by name in the Acknowledgments below.)

In this article, we report on the personal and professional life, ancestry and fate of this first female graduate in chemistry at Rostock University by compiling thorough genealogical research in connection with the career path of a Jewish female chemist in the first half of the twentieth century. To the best of our knowledge, this has not been done before. The main objective was not to write a semi-fictional or speculative narrative about Else Hirschberg's life, but to highlight the facts of her life, her outstanding scientific accomplishments, and the life of her family in representation of the uncountable personal histories and legacies of those Jewish Germans who were murdered in the Shoah.

The focus on the first female chemistry graduate of Rostock University became obvious due to the fact that, until now, the name of Else Hirschberg had been almost completely forgotten. By collecting genealogical as well as personal and professional information, this article also provides information about Else Hirschberg's academic career and scientific efforts which are extraordinary for the beginning of the twentieth century, especially in terms of women in science.

We dedicate this article to the memory of Else Hirschberg, in celebration of the 125th anniversary of her birthday and in commemoration of the 75th anniversary of her death during the Shoah.

\section{Else Hirschberg's ancestry and family tree}

Else Mathilde Erna Hirschberg (1) ${ }^{*}$ was born on 11 February $1892^{14}$ in Berlin, Prussia as the eldest child and daughter of the Jewish merchant (Kaufmann) Ludwig (Louis) Michael Hirschberg (1857-1920) and his Jewish wife Aurelie née Kroner (1868-1936). Her parents had married on 10 April $1888^{15}$ in Breslau, and the couple had three more daughters, who were all born in Berlin. Paula Gertrud Hirschberg (1a) was born on 30 April 1893, ${ }^{16}$ Bertha Hertha ${ }^{\dagger}$ Hirschberg (1b) was born on 10 January 1896, ${ }^{17}$ and Margot Emilie Hirschberg (1c) was born on 10 March $1900 .{ }^{18}$

The family moved to Ludwig Hirschberg's birthplace of Königsberg, Prussia (now Kaliningrad, Russia) ${ }^{19,20}$ shortly after the birth of daughter Margot, and lived there before the mother and her four daughters moved to Rostock, Mecklenburg-Schwerin in about 1908. Aurelie Hirschberg née Kroner can be found in the Rostock directories from 1908 onwards, at Schillerstraße $29^{21}$ where she lived until her death in 1936. She was one of the first renters. The house was erected in 1906 and a picture can be found online. ${ }^{22}$ The parents divorced between 1900 and 1908, which was a difficult decision, especially for Aurelie. Hints that the couple had struggles in their marriage can be found in the last will of Aurelie's mother. Ludwig Hirschberg became a railway director and stayed in Königsberg until his death. It is not known to which railway company he belonged.

\section{Paternal lineage - Hirschberg family branch}

An overview of Else Hirschberg's paternal lineage including her parents, grandparents and great-grandparents is depicted in an ancestry chart which can be found in Figure 2. An extensive ancestry chart showing all of Else Hirschberg's relatives can be found online. ${ }^{23}$

Thorough genealogical research allowed the Hirschberg family branch to be traced back to the beginning of the nineteenth century. This branch includes individuals who lived mainly in the Jewish community in Königsberg for three generations (Else Hirschberg's father, his parents and grandparents). Else Hirschberg's father, Ludwig Hirschberg (2), was born on 6 November $1857^{24}$ in Königsberg as the eldest child and son of the Jewish Morocco leather manufacturer (Saffianfabrikant) Moritz Hirschberg (c.1829-1865) (4) and his Jewish wife Bertha (Rebecca) née Theodor (1838-1902) (5).

Very little is known about Ludwig Hirschberg's life, career, and the circumstances regarding how he met his wife Aurelie Kroner in Breslau and why the family moved from Berlin back to his birthplace of Königsberg. It is known from the marriage certificate that he was a merchant living in Berlin in 1888, and that he was a divorced railway director when he died on 7 February $1920^{25}$ in Königsberg. It can only be speculated that the position of railway director was offered to him and he took this opportunity for advancement with the chance to return to his hometown.

Ludwig Hirschberg's parents married on 22 February $1856^{26}$ in Königsberg and had four more children. Their second child Ernst (Eliesar) Hirschberg (2a) was born on 8 March 1859 in Königsberg, ${ }^{27}$ Paul (Raphael) Hirschberg (2b) was born on 21 November 1860 in Königsberg, ${ }^{28}$ Robert Hirschberg (2c) was born on 4 September $1862,{ }^{29}$ and their only daughter, Flora Rahel Martha Hirschberg (2d), was born on 18 October 1864 in Königsberg. ${ }^{30}$

*Bold numbers in brackets after an individual's name indicate the genealogical numbering which can be found in ancestry charts (Figures 2 and 3). Lowercase letters following the genealogical numbers indicate siblings.

'Individuals' first names and surnames are given in full, if they are known by sources. First names by which someone is known other than the first in the row of first names are underlined. 


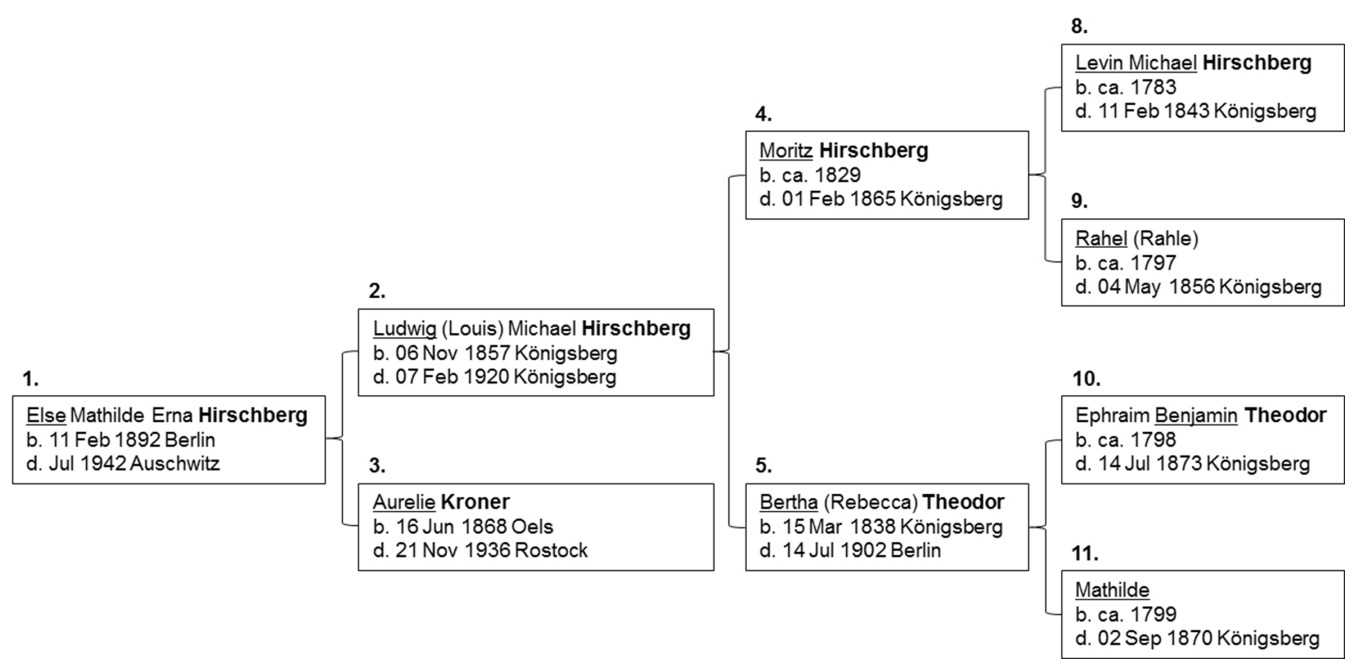

Figure 2. Else Hirschberg's paternal lineage, showing her parents, grandparents and great-grandparents.

Note: Genealogical numbers in bold are given above each individual; the first name by which someone is known is underlined; family names are in bold; dates of marriage are omitted.

Else Hirschberg's uncle Ernst Hirschberg (2a) married the Christian Johanna Louise Margarethe Müller on 15 November $1892^{31}$ in Schwerin, Mecklenburg-Schwerin. Ernst Hirschberg had converted to the Christian faith prior to his wedding and all the children were later baptised as Protestants. The married couple resided first in Berlin, and later in Charlottenburg, Prussia. At that time, Charlottenburg was an independent Prussian city (it was incorporated into Berlin in 1920). The couple had three children: a son named August Paul Hirschberg was born on 30 May $1893^{32}$ in Berlin, but died on 5 June $1893^{33}$ in Berlin. A daughter named Bertha Louise Gertrud Hirschberg was born on 14 September $1897^{34}$ in Charlottenburg, and a second son named Karl Theodor Paul Hirschberg was born on 6 August $1898,{ }^{35}$ also in Charlottenburg. The second son, Paul, died at the age of nineteen in World War I on 30 March 1918 in France. Paul Hirschberg is listed in the German World War I list of casualties published on 15 June 1918 and in the list of casualties of his regiment. $^{36,37}$

Ernst Hirschberg received his matriculation certificate in autumn 1878 in Königsberg, ${ }^{38}$ received his D.Phil. at the Albertus University in Königsberg on 13 February $1882^{39}$ and worked at the Statistical Office in Berlin between 1884 and 1897, before becoming the Director of the Statistical Office in Charlottenburg in $1897 .{ }^{40}$ Ernst Hirschberg (Figure 3) died on 22 June $1906^{41}$ in Charlottenburg. Unfortunately, we have not been able to get further information on the fate and later life of the widow Margarethe Hirschberg. Only one single source mentions her residence along with her parents again back in Schwerin in $1919 .{ }^{42}$

Ernst Hirschberg's only daughter Gertrud Hirschberg married the master builder (Regierungsbaumeister) Erwin Münz on 6 July $1916^{43}$ in Karlsruhe, Baden. Erwin Münz was born on 27 June $1882^{44}$ in Villingen, Baden and the later life of Gertrud and her husband Erwin Münz could only be traced until World War II in Königsberg, where their son Rainer Münz was born on 27 March 1920.45 He died in World War II on 17 September 1941 in Russia. ${ }^{46}$ Erwin Münz had lived in Königsberg since World War I and later became the railway director of the Ostdeutsche Eisenbahn-Gesellschaft in Königsberg, which was located in the northern station (Nordbahnhof). He died in early 1945 in Königsberg after being maltreated by the Russian State Political Directorate (GPU). ${ }^{47}$

Unfortunately, nothing more is known about further descendants of Ernst Hirschberg or their fates. The most interesting fact is the connection between Karl Münz and Else's father Ludwig, who were both working as railway directors in Königsberg. It was not possible to investigate whether they were working for the same railroad company, but it is possible that Else's father helped Erwin, his niece's husband, to get a position in Königsberg. However, the knowledge that the deportation of Jews in Königsberg started from the northern station in the summer of 1942 casts a dark light on this family connection.

Very little is known about Else Hirschberg's uncle Paul Hirschberg (2b) and his early life in Königsberg. He worked as a trainee in the public construction management (Königlicher Regierungsbauführer) in Berlin and died unmarried at the age of twenty-seven on 24 February 1888 in Berlin. ${ }^{48}$ 


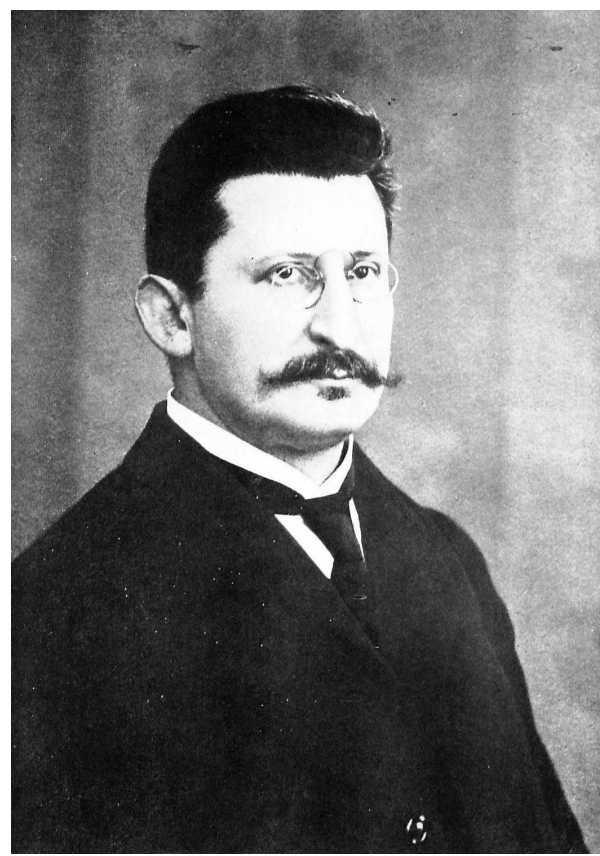

Figure 3. Ernst Hirschberg (1859-1906) (2a), c.1900.

Else Hirschberg's uncle Robert Hirschberg (2c) married Margarethe Caro on 13 September 1894 in Berlin. ${ }^{49}$ Margarethe Caro had been born on 27 June $1870^{50}$ in Berlin, to the Jewish merchant Julius Caro and his wife Fanny Bergmann. The married couple resided in Königsberg, where Robert Hirschberg was an accountant and later co-owner of a laundry factory (Dampf-, Wasch- und Plättanstalt Barschall \& Co.). ${ }^{51}$ Robert Hirschberg's wife Margarethe died on 28 October 1914 in Königsberg. ${ }^{52}$ It is not known if the couple had any children. Robert Hirschberg must have died after 1920, but an exact death date could not be determined. Robert Hirschberg is mentioned in his brother Ludwig Hirschberg's death registry entry from 1920 as the informant. ${ }^{53}$

Else Hirschberg's only direct paternal aunt, Flora Hirschberg (2d), married the chemist Felix Victor Heinrich Weger on 26 July 1890 in Berlin. ${ }^{54}$ Felix Weger was born on 13 December $1859^{55}$ in Königsberg, and the marriage entry states that the husband was not of the Jewish faith, but belonged to a Reformed Church (deutsch-reformierte Kirche). He was baptised on 10 June $1860^{56}$ at the Burgkirche in Königsberg. Felix Weger received his D.Phil. as a chemist at Albertus University in Königsberg on 14 April $1883 .{ }^{57}$ The couple resided in Berlin, where Felix Weger worked as a chemist until his death on 17 February $1903 . .^{58}$ One known son named Otto Paul Hermann Weger was born on 3 November 1893 in Berlin. ${ }^{59}$ He was a pilot in World War I, who died on 30 July 1918 in an air crash in the Jordan River valley. He was a scanner, shot down by E. P. Kenny and L. W. Sutherland (No. 1 Sqn AFC) and is buried in Nazareth. ${ }^{60,61,62}$ His widow Flora moved to a retirement home in 1928 in Berlin and lived there until she was deported on 4 August 1943 to Theresienstadt concentration camp, where she was murdered on 6 February $1944 .{ }^{63}$ Figure 4 shows the Stolperstein commemorating her death. ${ }^{64}$ A Stolperstein (stumbling block) is a special cobblestone created in memory of deported Jews. This project was developed by the German artist Gunter Demnig.

\section{Maternal lineage - Kroner family branch}

Else Hirschberg's maternal ancestors do not belong to Jewish families from East Prussia, but have long traditions among Silesian and Neumark Jewry. Her maternal lineage including her parents, grandparents and great-grandparents is depicted in Figure 5. Else Hirschberg's mother Aurelie née Kroner (3) was born on 16 June $1868^{65}$ in Oels, Silesia (now Oleśnica, Poland) as the youngest child and only daughter of Rabbi Aron (also Ahron) Kroner (6) and his wife Frommut (also Frommuth, Frommit) née Brody (7). As already mentioned above, Aurelie married Ludwig Hirschberg in 1888, they resided in Berlin and the couple had four daughters.

The last will of Aurelie Hirschberg's mother from 1903 indicates that the married couple may have had severe struggles within their marriage, and that the marriage was not a happy one. Frommuth Kroner's last will ${ }^{66}$ states:

Meine Tochter wohnt jetzt in Königsberg Schönstr. 11. Ich wünsche nicht, daß das Gericht sich einmischt. Meine geliebten Söhne, wenn Gegenstände da sind, die Ihr beide gern haben möchtet, so läßt das Loos entscheiden \& entzweit Euch deshalb nicht, denn ich hänge an jeden einzelnen meiner Kinder mit großer Innigkeit \& Liebe, da meine Kinder meine Welt sind. Verläßt Eure Schwester nicht, sie hat ein besseres Loos verdient. Ihr habt bloß die Eine Schwester. 
My daughter lives now in Königsberg, Schönstr. 11. I do not wish any intervention by the court. My beloved sons, if there are any items you like to have, please toss up for them and do not fall out with each other because I am attached to every child with great heartiness and love because my children are my world. Do not leave your sister, she deserves better. She is your only sister.

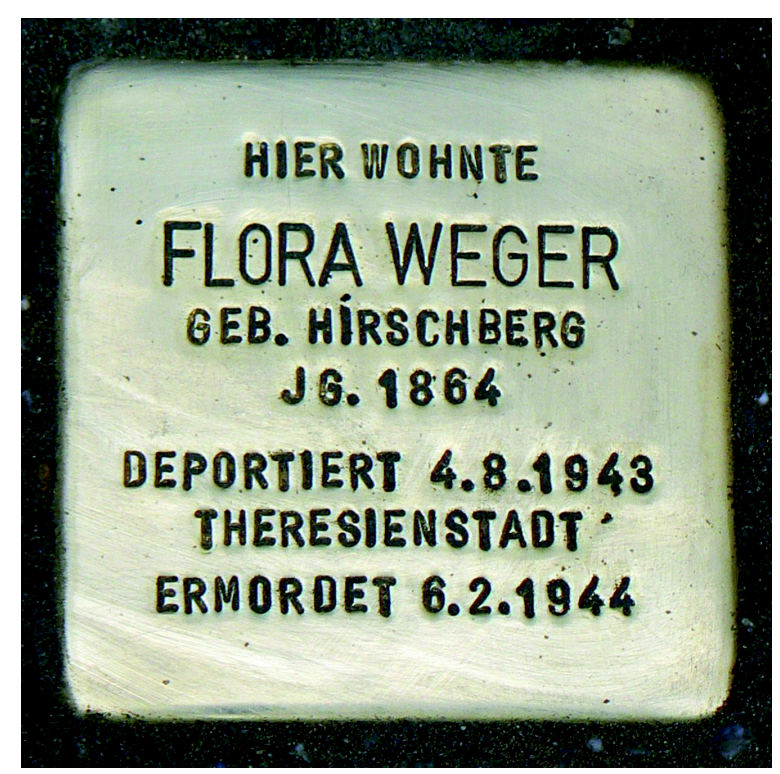

Figure 4. Stolperstein in commemoration of Flora Weger's death during the Shoah. Published with permission.

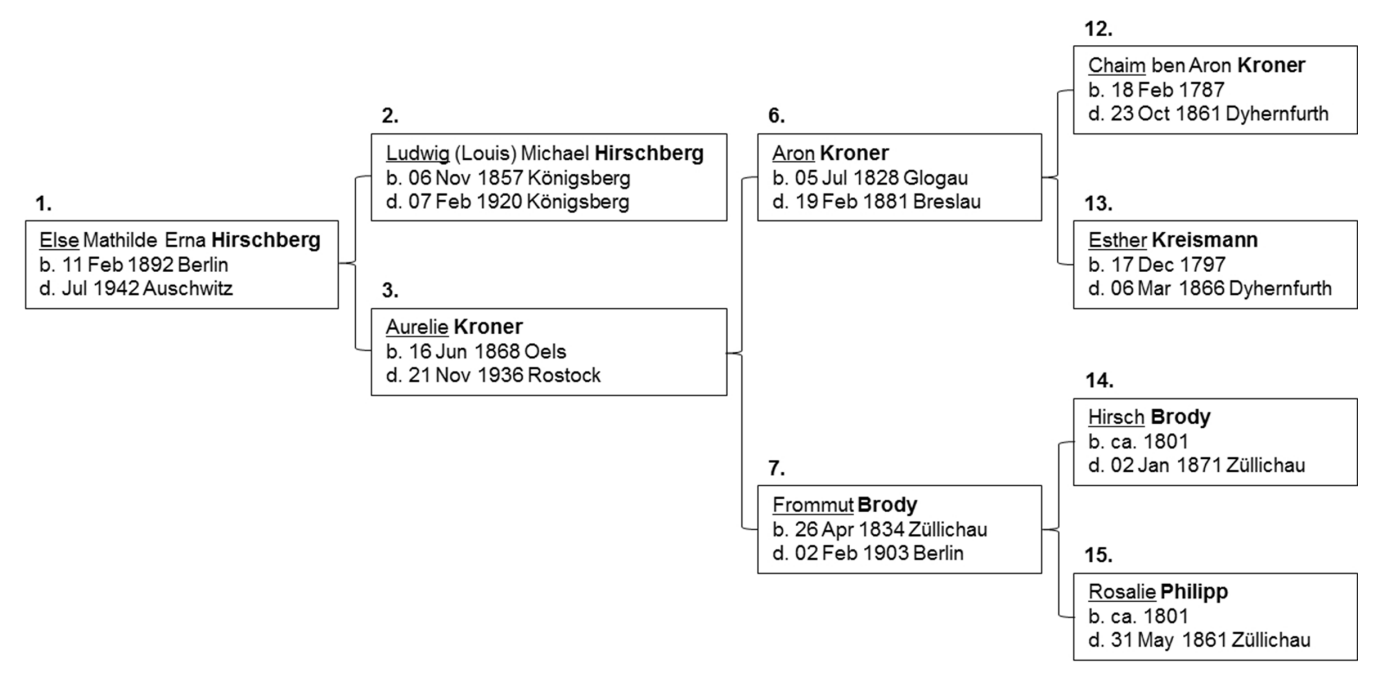

Figure 5. Else Hirschberg's maternal lineage showing her parents, grandparents and great-grandparents.

The couple divorced before 1908. It can only be speculated that the absence of a son, the relocation to the husband's birthplace or leaving the wife's family behind in Berlin led to these struggles and resulted in the dissolution of the marriage. We do not know why Aurelie moved with her four young daughters to Rostock in Mecklenburg-Schwerin in 1908, a town with a rather small Jewish community and where she had no relatives. Maybe Aurelie's divorce led to a stigma for her that made it impossible to return to her family in Berlin. Figures 6 and 7 show Aurelie (c.1888) and her gravestone at the Jewish cemetery in Rostock.

Aurelie Kroner's parents had married on 15 January $1856^{69}$ in Züllichau, Neumark (now Sulechów, Poland) and the couple had two more children. The eldest son, Siegfried Kroner (3a), was born on 10 June $1858^{70}$ in Fraustadt, Posen (now Wschowa, Poland), and a second son, Hugo Kroner (3b), was born on 11 May $1863^{71}$ in Oels. Rabbi Aron Kroner can be found in a biographical handbook of German rabbis, ${ }^{72}$ but prior to this research very little has been known about his life, family and ancestry. Aron Kroner (6) was born on 5 July $1828^{73}$ in Glogau, Silesia (now Głogów, Poland) to Rabbi Chaim ben Aron (also known as Hayyim, Mose Chajim, Levin Heimann, and Lewin Gedalje) Kroner (1787-1861) 

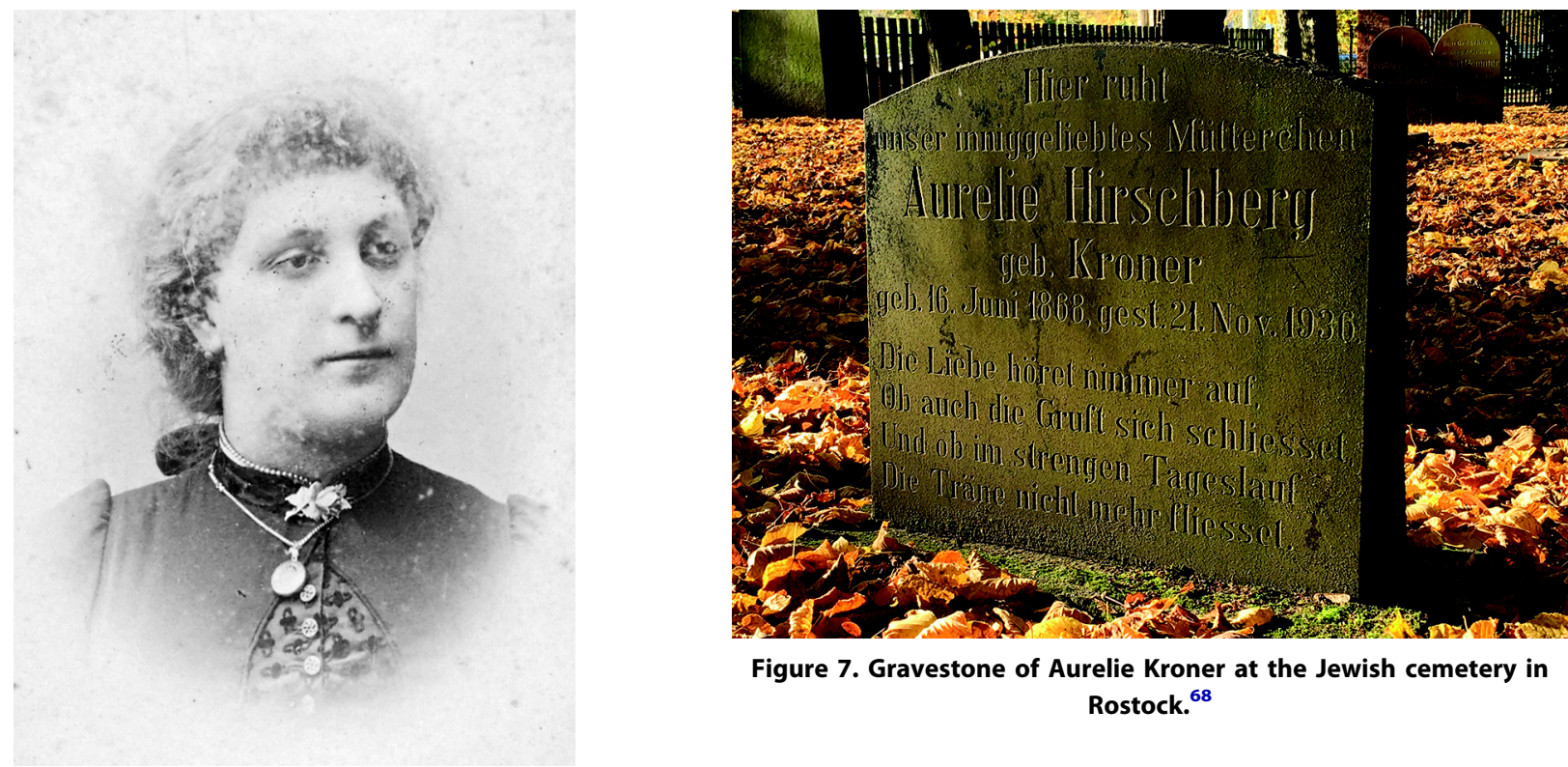

Figure 7. Gravestone of Aurelie Kroner at the Jewish cemetery in Rostock. ${ }^{68}$

Figure 6. Aurelie Kroner (3). ${ }^{67} \odot$ Centre for German-Jewish Studies, University of Sussex.

(12) and his wife Esther (or Ernestine) née Kreismann (1797-1866) (13). The Kroner family moved in 1830 from Glogau to Dyhernfurth, Silesia (now Brzeg Dolny, Poland), where Aron Kroner's father, Chaim ben Aron Kroner, was the last rabbi of the Jewish community until his death in 1861.

Aron Kroner attended the local grade school in his hometown Dyhernfurth, undertook Talmudic studies at the age of fifteen outside his hometown and moved to Berlin at the age of eighteen in 1846 to attend Rabbi Jakob Joseph Öttinger's (1780-1860) yeshiva. ${ }^{74}$ Aron Kroner enrolled at Friedrich-Wilhelms-Universität zu Berlin (now Humboldt University of Berlin) in October 1850 and stayed until November $1854 .{ }^{75} \mathrm{He}$ received his D.Phil. at the University of Jena on 16 November $1854 .{ }^{76}$ (A previous attempt to receive a doctorate had been rejected by the University of Kiel in 1854. ${ }^{77}$ ) Rabbi Aron Kroner moved to Polnisch Wartenberg (also known as Groß Wartenberg), Silesia (now Syców, Poland) in January 1856 and later to Fraustadt in April $1858 .{ }^{78}$ The family later moved to Oels in 1860, where Aron Kroner stayed until $1871 .{ }^{79}$ After Rabbi Kroner's retirement the family moved to Breslau, where he died at the age of only fifty-two on 19 February $1881 .{ }^{80}$ He was buried on 21 February 1881 at the Old Jewish Cemetery in Breslau. (Aron Kroner's original gravestone and a recent picture of the site are depicted in Figures 8 and 9.)

Aron Kroner's wife Frommut Kroner née Brody (7) was born on 26 April $1834^{83}$ in Züllichau to Jewish parents Hirsch Brody (c.1801-1871) (14) and Rosalie née Philipp (c.1801-1861) (15). She died more than twenty years after her husband on 2 February 1903 in Berlin. ${ }^{84}$ She was buried on 6 February 1903 in Weißensee Jewish Cemetery. ${ }^{85}$

Else Hirschberg's maternal uncle Siegfried Kroner (3a) married Regina Mallachow on 19 May 1890 in Berlin. ${ }^{86}$ (See Figure 10 for their photograph.) Regina Mallachow was born on 10 November $1866^{87}$ in Bromberg, Posen (now Bydgoszcz, Poland). The married couple resided in Berlin and had three children. Their eldest child Eveline Erna Kroner was born on 16 April 1891 in Berlin ${ }^{88}$ and married the engineer Paul Bernard Federmann on 6 May 1913 in Wilmersdorf. ${ }^{89}$ The couple's divorce was finalised on 23 November 1926 in Berlin, and Eveline emigrated to England, where she died on 2 January 1983 in London. ${ }^{90}$ Paul Federmann had been born on 20 April 1888 in Berlin ${ }^{91}$ and after deportation to Auschwitz in May 1943 it is likely that he was murdered there. ${ }^{92}$ Siegfried and Regina Kroner's second child Alice Margarethe was born on 20 August 1894 in Berlin. ${ }^{93}$ She also emigrated to England and died on 27 January 1949 in Birmingham. ${ }^{94}$ The couple's last child (and only son), Erwin Wilhelm Kroner, was born in November 1905 in Charlottenburg and died at the very young age of five on 23 August 1911 in Charlottenburg. ${ }^{95}$ He was buried on 25 August 1911 at Weißensee Jewish Cemetery in Berlin. ${ }^{96}$

Else Hirschberg's second maternal uncle, Hugo Kroner (3b) (Figure 11), married Clara Lehwess on 17 October 1892 in Berlin. ${ }^{97}$ Clara Lehwess was born on 12 March 1868 in Wielowies, Posen to Emil Lehwess and his wife Helene née Suesskind (also Siesskind or Sieskind). (The place name Wielowies is ambiguous: Wielowies can either be Wielowieś, Gmina Pakość, Poland or Wielowieś, Gmina Gniewkowo, Poland. Both Pakość and 


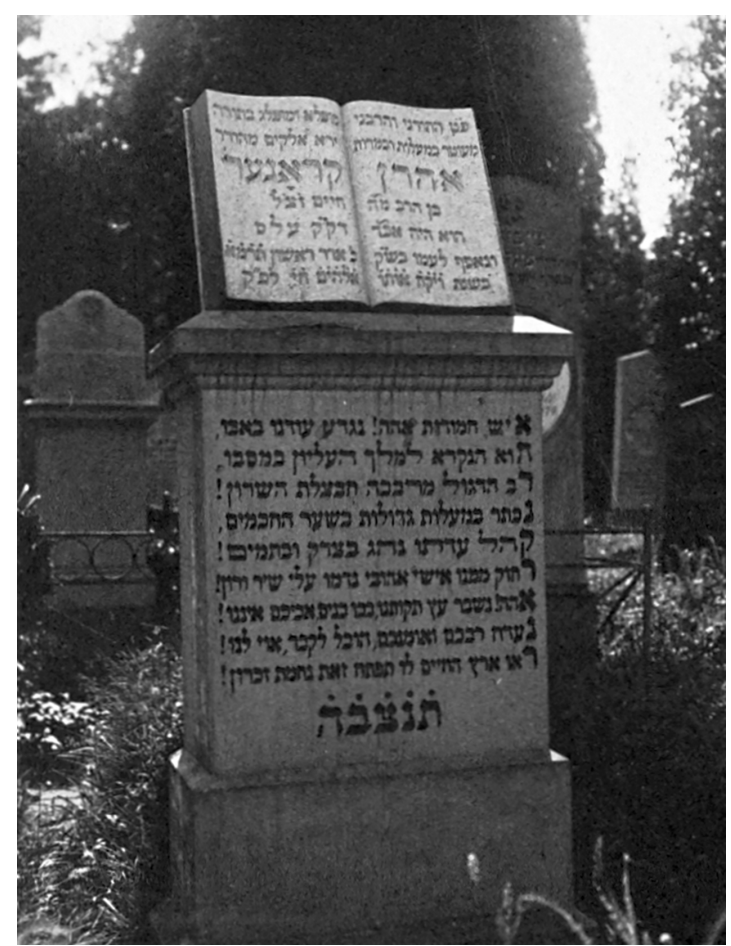

Figure 8. Aron Kroner's original gravestone. ${ }^{81} \odot$ Centre for German-Jewish Studies, University of Sussex.

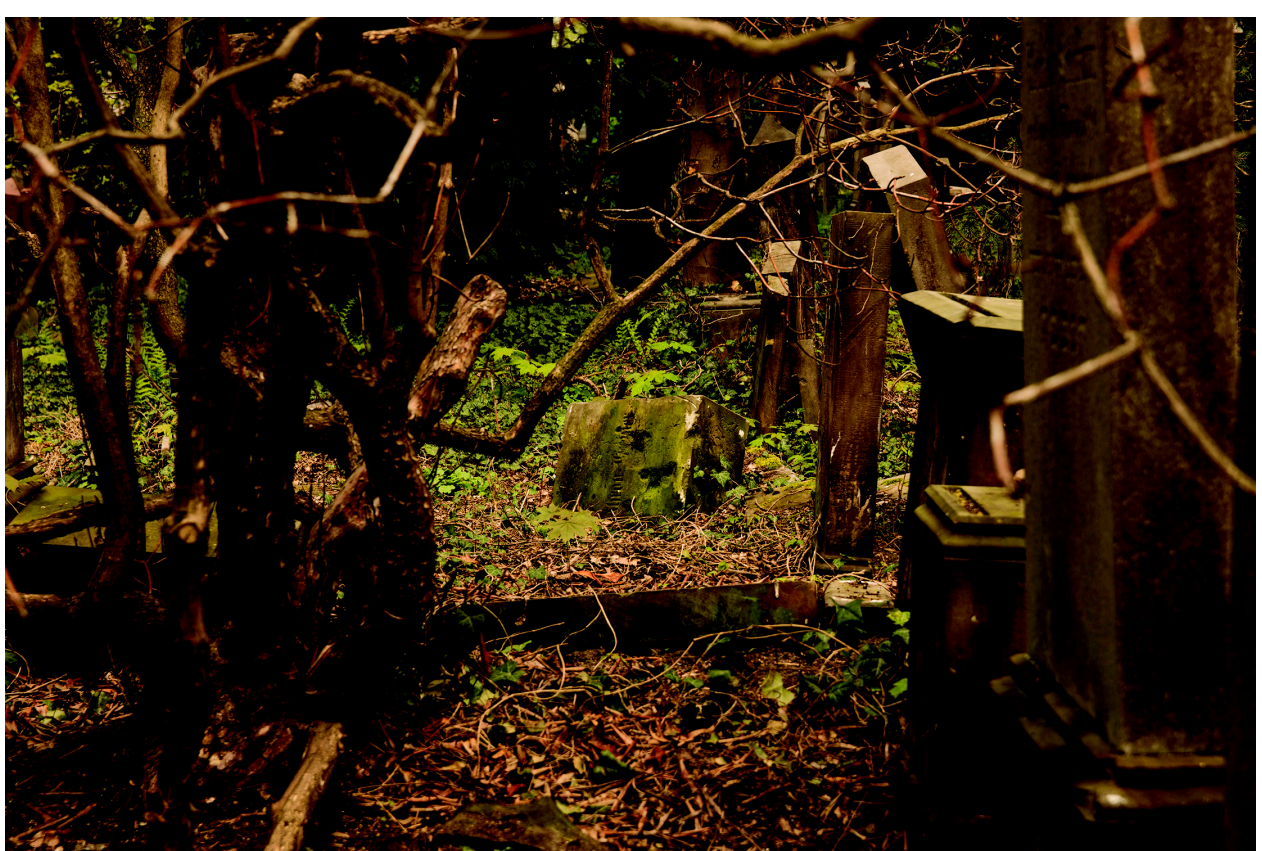

Figure 9. The ruined site of Aron Kroner's grave at the Old Jewish Cemetery in Breslau. ${ }^{82}$

Gniewkowo had Jewish communities.) The couple resided in Berlin and had two sons. The first son, Alfred Aron Kroner, was born on 19 September 1894 in Berlin ${ }^{98}$ and was married to Thea Lammfromm. Thea and Alfred Kroner emigrated to the USA in November 1938, ${ }^{99}$ where Alfred died on 13 January $1977^{100}$ and Thea on 15 December $1991 .^{101}$ Clara and Hugo Kroner's second son, Emil Curt Kroner, was born on 14 December 1899 in Berlin. ${ }^{102} \mathrm{He}$ emigrated to the USA in November $1936^{103}$ and resided his whole life in New York City until his death on 17 February $1988 .{ }^{104}$ His life companion, Rolf Leo Hirschberg (1902-2002) (not related to Else Hirschberg's Königsberg family branch), was interviewed in October 1996 about their lives as Jewish homosexuals, especially during the Nazi era, as part of the United States Holocaust Memorial Museum oral history collection. ${ }^{105}$ After his wife's death, Hugo emigrated to the USA in December $1938,{ }^{106}$ where he died on 21 March $1939 .{ }^{107}$ 


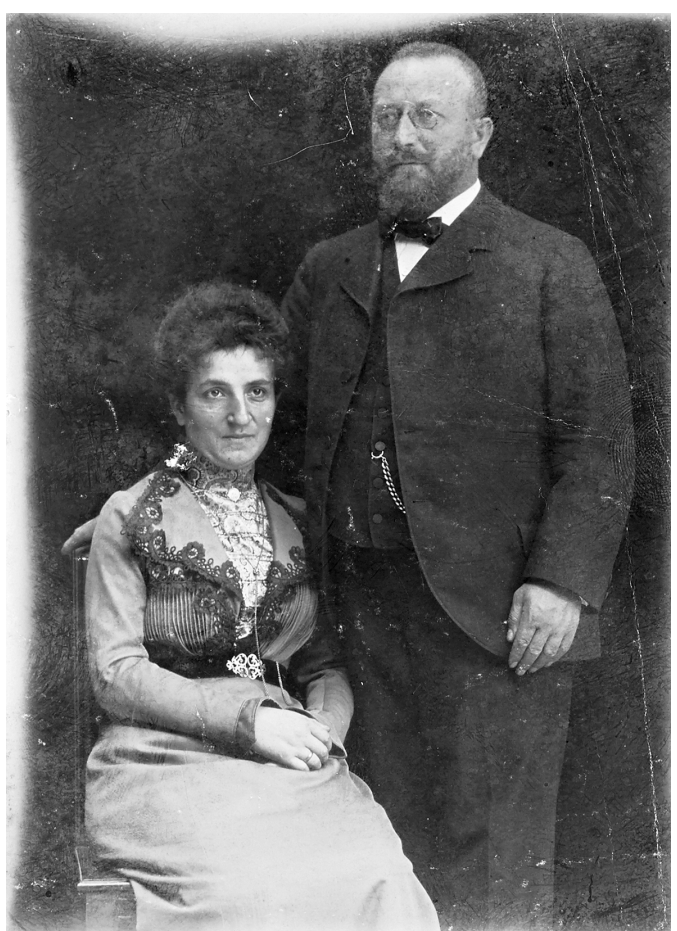

Figure 10. Else Hirschberg's paternal uncle Siegfried Kroner (1858-1913) (3a) with his wife Regina née Mallachow (1866-1908) (c.1900). ๑ Centre for German-Jewish Studies, University of Sussex.

Hugo Kroner can be found in the Breslau City Directory of 1885 for the first time, where he is mentioned as a merchant with his own office at the Breslauer Tinte- und Lackfabrik. ${ }^{109}$ In the Breslau city directory of 1890 neither he nor his widowed mother can be found, so they must have moved prior to 1890 to join Hugo's brother Siegfried, residing in Berlin. A joint business of Hugo and his brother Siegfried (Gebrüder Kroner, Chemische Fabrik) can be found in Berlin from 1890 until 1937, where they produced inks, varnish, grease, isinglass, dubbin, and lubricants as well as detergents and shoe polish. The joint factory was established on 1 April 1884 and celebrated its fortieth anniversary in 1924, with a newspaper article in the Berliner Tageblatt. ${ }^{10}$ Addresses in Berlin were: Annenstraße 14 (1890-1892), Hagelbergerstraße 6 (1893-1899), Bergstraße 55/56, Rixdorf (1900-1901), Alexandrinenstraße 119/120 (1902-1906), Warschauer Straße 34-36 (1907-1936), Potsdamer Straße 122 (1937). ${ }^{111}$ Figure 12 shows the three Kroner siblings Siegfried, Hugo and Aurelie and their relatives.

Before Siegfried Kroner ran his own business he had been employed at merchant S. Zimmt in Breslau (1877-79), as a clerk at merchant Louis Lohnstein in Breslau (1880), as a travelling salesman at Burchardt's Fabrik-Waaren-Haus in Berlin (1881), from July 1881 until March 1882 also as a travelling salesman at Adolph Lehmann Wachstuch- \& Rouleaux-Fabrik in Berlin (1881-82), and as a salesman at S. Tuchband Sammet- und Seidenwaaren in Berlin (1883). ${ }^{112}$ Siegfried Kroner's wife Regina died on 7 March 1908 in Berlin, ${ }^{113}$ and five years later Siegfried Kroner himself died on 21 November 1913 in Berlin. ${ }^{114}$ They are both buried at the Weißensee Jewish Cemetery in Berlin. ${ }^{115,116}$

After his brother's death, Hugo Kroner was the sole owner of the factory. In 1921 his sons Alfred and Emil became general managers and in 1925 personally liable shareholders. ${ }^{117}$ In 1934 Hugo left the chemical factory. The company had to be sold in June 1936 to Pfeilring-Werke A. G. ${ }^{118}$ and in 1937 it was deleted from the German company register (Handelsregister). ${ }^{119}$ In the 1950s and 1960s Alfred and Emil struggled for compensation for the forced sale of their chemical factory. ${ }^{120}$

Genealogical research has shown that almost all of Else's maternal relatives had the opportunity to emigrate to England or the USA and so survive the Shoah. Knowing this, Else's and her sister's dramatic fate becomes even more devastating and tragic.

\section{Origins of the surname Kroner}

In 1812 Jewish inhabitants in Prussia were allowed to become Prussian citizens (Staatsbürger) by the edict concerning the civil circumstances of the Jewish citizens in Prussia (Edikt betreffend die bürgerlichen Verhältnisse der Juden in dem Preußischen Staate) granted by Frederick William III of Prussia (1770-1840), which was an important milestone in the lawful equality of Jews in Prussia. ${ }^{121}$ One major requirement to become a lawful citizen of Prussia was to adopt a permanent surname. 


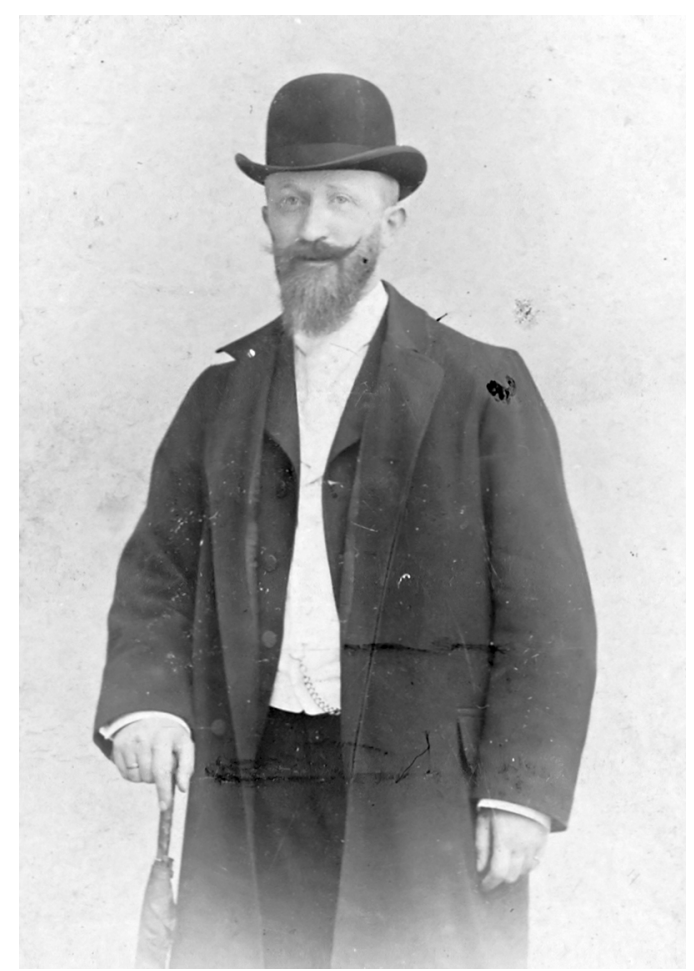

Figure 11. Else Hirschberg's uncle Hugo Kroner (1863-1939) (3b) (1901). ${ }^{108} \odot$ Centre for German-Jewish Studies, University of Sussex.

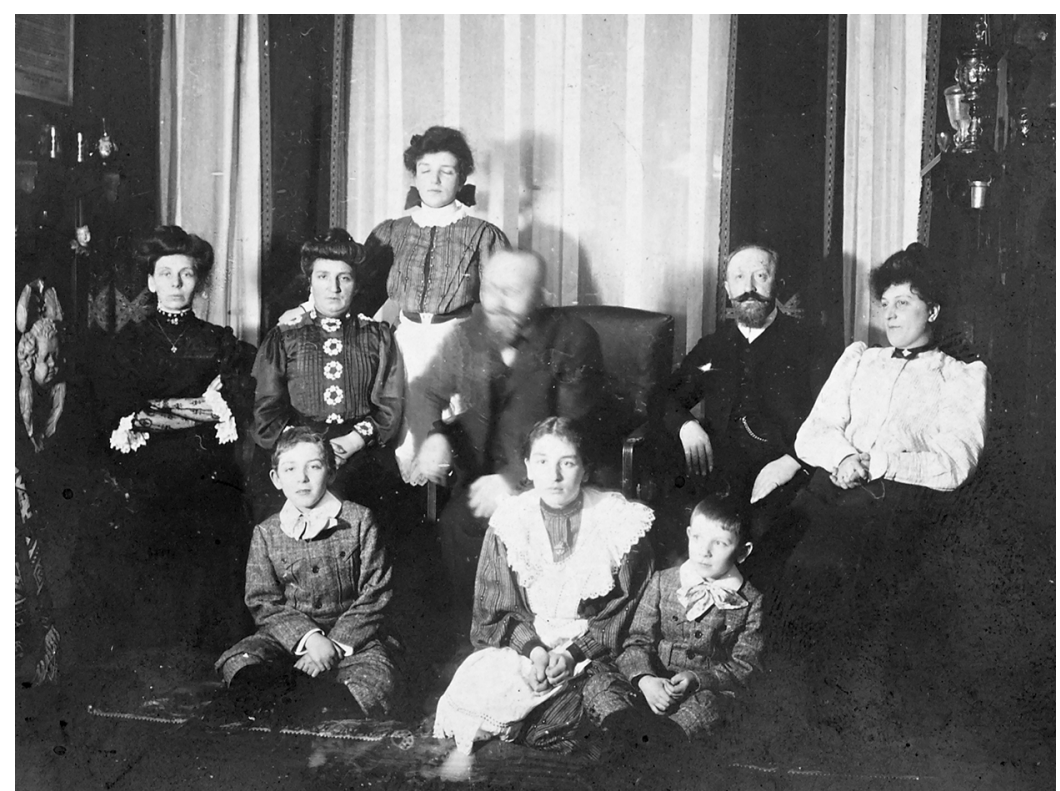

Figure 12. The Kroner siblings and their families, Berlin, 1906. $\odot$ Centre for German-Jewish Studies, University of Sussex. From I. to $r$. Clara Kroner née Lehwess (1868-?), Alfred Aron Kroner (1894-1977), Regina Kroner née Mallachow (1866-1908), Eveline Erna Kroner (1891-1983), Siegfried Kroner (1858-1913) (3a), Alice Margarethe Kroner (1894-1949), Emil Curt Kroner (1899-1988), Hugo Kroner (1863-1939) (3b), and Aurelie Hirschberg née Kroner (1868-1936) (3).

Aron Kroner's (6) father, the producer of signets (Petschierstecher) Lewin Gedalge (12), who is also known as Levin Gedalje and later known as Rabbi Chaim ben Aron Kroner in Dyhernfurth, became a lawful Prussian citizen in Schloppe, West Prussia (now Człopa, Poland) on 9 March 1813 by adopting the surname Kroner. ${ }^{122}$ It is interesting to know that Schloppe belonged to the so-called Kroner Land which was a region 


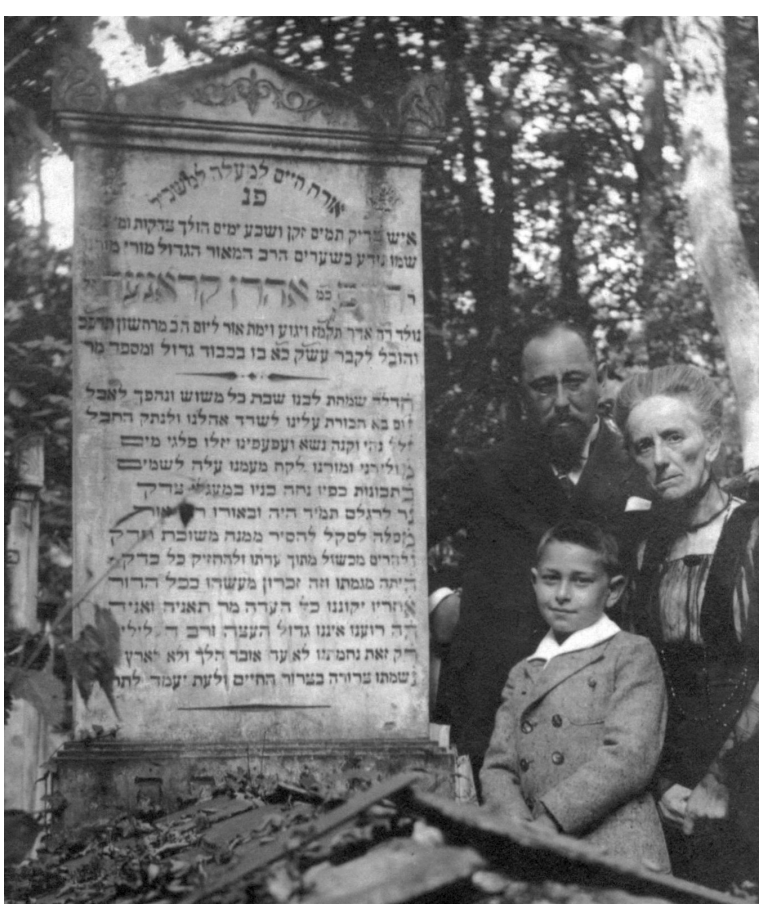

Figure 13. The gravestone of Lewin Gedalge Kroner (later Rabbi Chaim ben Aron Kroner) (1787-1861) (12), with unknown family members at the Jewish cemetery in Dyhernfurth in $1909 .^{126}$

north of the river Netze (Noteć, Poland). Schloppe became part of the so-called Landkreis Deutsch Krone on 1 April 1818, when Prussia was organised into districts (Kreise) after the Congress of Vienna. ${ }^{123}$ It is possible that Lewin Gedalge chose the surname Kroner based on the region where he lived.

Another interesting explanation of why the family adopted the surname Kroner is given by Rabbi Chaim Kroner's daughter, Fanni Weinbaum (c.1832-c.1914), in Rabbi Grünwald's publication about the history of the Jewish community in Dyhernfurth. ${ }^{124}$ She states that her father was a student at the Academy of Arts of Berlin (Königlich Preußische Akademie der Künste) and he especially distinguished himself in drawing crowns (in German, Krone), hence the king ordered him to bear the surname Kroner.

Within the students' registers of the Academy of Arts of Berlin only one single entry can be found which could be the later Rabbi Chaim Kroner: from April 1814 to March 1815, Heinrich (a common non-Jewish transformation for Chaim) Krohne, twenty-six years old (born c.1788), was enrolled in the tinsmith (Klempner) class at the Academy. Heinrich Krohne's birthplace is given as 'Holstein in Braunschl.', which is not only ambiguous but also unassignable to a geographic place or region. ${ }^{125}$ It is possible that Heinrich Krohne is Chaim Kroner, due to the fact that he was a producer of signets prior to becoming a rabbi. In addition, the calculated birth year is in very good agreement with Rabbi Chaim ben Aron Kroner's actual year of birth, which is listed on his tombstone (see Figure 13). Transcriptions of the inscriptions of Rabbi Chaim ben Aron Kroner's gravestone as well as of his wife Esther née Kreismann can be found in Grünwald's publication. Interestingly, Rabbi Chaim ben Aron Kroner is buried in a sarcophagus, rarely found in Jewish cemeteries and almost exclusively used for prominent members of the community.

In conclusion, both explanations of the origins of the surname Kroner can be considered, but ultimately no final truth can be stated.

\section{Else Hirschberg's professional development}

At a time when women were a rarity in universities, Else Hirschberg started an academic career. For a better understanding of her decision, the genealogical information above shows us that some of her relatives - especially on her paternal side - were academics. At the start of the twentieth century, the number of Jewish students in chemistry was relatively high. A study of chemistry opened the door to a remarkable career in the chemical industry. 


\section{Chemistry studies}

Else Hirschberg was a guest auditor at Rostock University from 1908 to $1912 .{ }^{127}$ As mentioned above, Rostock University did not allow the enrolment of female students until 1909 and Else never regularly enrolled as a student in chemistry. Referring to Else Hirschberg's CV in her dissertation from 1928, she had attended schools in Berlin, Königsberg and Rostock and left without final secondary-school examinations (Abitur) in 1908. ${ }^{128}$ Besides her chemistry studies at Rostock University, Else worked at the Institute of Hygiene under the supervision of Ludwig Pfeiffer (1861-1945). After successfully passing the Verbandsexamen, she did research work under the supervision of August Michaelis. The certificate of her Verbandsexamen is dated 25 July $1913 .{ }^{129}$ In order to receive a doctorate, she prepared a thesis and applied for admission to the doctoral programme. But a dispensation from the requirement of the final secondary-school examinations (Abitur), which was part of the promotion regulations (Promotionsordnung) at the Faculty of Philosophy of Rostock University was not permitted on 19 August 1913: "Der erbetene Dispens von der Vorschrift des \$2 Absatz 2a der Promotionsordnung der philosophischen Fakultät der Universität Rostock vom 11. Januar 1913 kann nicht erteilt werden." ${ }^{130}$

Else Hirschberg's first scientific publication dated from 1913 and dealt with the quantitative determination of small amounts of glucose in human urine. ${ }^{131}$ This research was done in the Medical University Hospital under the supervision of Friedrich Martius (1850-1923) and Joseph Meinertz (1877-1968), and it seems that Else Hirschberg's research preferences turned toward medical chemistry.

\section{Works in the field of pharmacology and physiology}

First, Else Hirschberg worked on pharmacological problems. Together with the pharmacologist Rudolf Kobert (1854-1918), she investigated some components of the lily of the valley (Convallaria majalis) and their pharmacological effects. The results were published in Kobert's monography about saponins, which are chemical compounds found in a variety of plant species. ${ }^{132}$

Else Hirschberg's titles changed over the years from helper (Hilfsarbeiterin) to technical assistant (technische Assistentin) and in 1917 Else was offered a position as an assistant at the Institute of Physiology by Hans Winterstein (1879-1963). ${ }^{133}$ She worked there until 1933 with some interruptions. From 1918 to 1919 she replaced the Head of the metabolism laboratory (Stoffwechsel-Laboratorium) at the municipal hospital in Stettin, Pomerania (Szczecin, Poland). There she also started scientific work that could not be finished because the regular Head returned from World War I. ${ }^{134}$ She worked with Peter Rona (1871-1945) in Berlin and in 1923 did some research work for the chemical factory of Dr. Christian Brunnengräber and for the dairy (Dampfmolkerei) of Heinrich Wiencke. ${ }^{135}$

At the Institute of Physiology from 1917 to 1919 under the supervision of Hans Winterstein, Else authored or co-authored a number of publications that dealt with investigations on sugar and fat metabolism in the central nervous system and narcotics. Between 1925 and 1927 they published studies about metabolism in the central nervous system as well as ammonia formation within the central nervous system, the solubility of chloroform in the blood, the permeability of muscle membranes, and muscle stimuli. (See Appendix A for the list of her publications.)

In 1927, Winterstein left Rostock to become a professor at Breslau University. Friedrich Fröhlich (1879-1932) followed Winterstein as Professor of Physiology. Else continued with scientific work and published several more papers. Her publication index comprises twenty-three documents in total: twenty-one articles in scientific journals, one book chapter and one dissertation. This amount of publications is rather unusual for fewer than twenty years of research in those war and interwar times, especially for a female researcher. It is important to note that her publications have now been rediscovered after having fallen into oblivion. More than ever it is important to list and describe Else's complete scientific works in order to show her diversity and great inter- and multidisciplinary skills in the fields of inorganic, organic and physical chemistry, pharmacology, physiology, and biology.

But what was everyday research life like for Else Hirschberg, being only an assistant, but not a member of the research staff at the Institute of Physiology? She was only employed as an assistant at Rostock University until 1933 because she had no medical education, which was one of the requirements to become a regular member of the research staff. It is known from her university dossier that her salary was about 200-250 reichsmarks (for comparison 200 reichsmarks in 1926-1936 correspond to $€ 830$ in 2015), ${ }^{136}$ and her requests and those of her supervisors to increase her salary were always declined. ${ }^{137}$ Her area of responsibilities nevertheless included assistance with lectures and courses, managing the Institute's library, registration of inventory and invoices as well as preparation of chemical solutions for lectures and courses.

Mainly in order to finally get regular employment, Else Hirschberg tried to enrol for medical studies. The prerequisite was the final secondaryschool examination which Else did not have. In 1923, regulations in Prussia were established by a special decree for gifted individuals who could not complete university studies in the ordinary way (e.g. without having final secondary-school examinations) to gain access to universities. ${ }^{138}$ Else took advantage of this opportunity and passed the examination in Berlin in 1927. This allowed her to study natural 
sciences and medicine, not only in Berlin, but also in Rostock. ${ }^{139}$ With this document it was also possible for her to receive her doctorate. She attached a paper of her research results about the lily of the valley from 1917 to her doctoral request (Promotionsgesuch). The first referee, Richard Stoermer (1870-1940), Professor of Organic Chemistry, evaluated her dissertation and stated that for the first time precise and feasible methods for the separation of the chemically active substances from the lily of the valley were established, and that this represented considerable progress in comparison to older techniques. ${ }^{140}$ Stoermer considered Else Hirschberg's dissertation to be in the frontier zone between chemistry and pharmacology, and recommended it for acceptance.

The pharmacological part of her dissertation was examined by pharmacologist Ernst Frey (1878-1960), and he concluded that the dissertation was rather good, but that there were some issues with the dissertation having been published earlier. The Dean of the Faculty of Philosophy at Rostock University, David Katz (1884-1953) referred to a similar case and, because Else Hirschberg's former publication was not previously referenced, it was considered to be 'new'. That judgement was supported by all faculty professors and Else Hirschberg's final oral examination in chemistry, physics and physiology was held on 17 March 1928 with the final grade 'rite' (sufficient).

\section{Growing repression against Jewish staff members at Rostock University}

With the certificate, Else enrolled for medical studies at Rostock University on 21 June $1928 .{ }^{141}$ She was faced with hostility again and again in the following period. It is known from a letter dated 21 September 1931 that her qualifications and her employment status were consistently questioned. ${ }^{142}$ Friedrich Fröhlich defended her, especially by mentioning that she achieved a high reputation among the student body because of her helpfulness and her reliability, and because she attended all lectures and courses although she worked sixty hours a week as an assistant. Furthermore, she was also defended by the Dean of the Faculty of Medicine, Wilhelm von Gazen (1883-1936).

Despite the significant problems with her employment and the growing repression against Jewish people in Germany, Else worked at the Institute of Physiology until her dismissal in 1933. On 6 April 1933, Else Hirschberg informed the Deputy Director of the Institute of Physiology that she would stay absent from the Institute, as a consequence of the intentions of the leader of the local Nazi student association (Nationalsozialistischer Deutscher Studentenbund) Werner Trumpf (1910-1971). Fröhlich's successor at the Institute of Physiology, Kurt Wacholder (1893-1961) immediately tried to find a substitute for Else Hirschberg, and she was officially dismissed on 5 May 1933 (effective date: 1 July 1933) due to $\$ 3$ (Aryan paragraph) under the law for the Restoration of the Professional Civil Service (Gesetz zur Wiederherstellung des Berufsbeamtentums). Until 30 September 1933 she was put on paid leave. ${ }^{143}$

\section{Move to Hamburg and work at the Jewish hospital}

After Else Hirschberg's dismissal from Rostock University she stayed in Rostock, probably because she felt responsible for her mother Aurelie and her youngest sister Margot. But the financial basis for their life is unknown. On 21 November 1936, her mother Aurelie died and Else and her sister moved to Hamburg. They lived there in Wiesenweg $26 .{ }^{144}$ It was common for Jewish citizens to try to stay in bigger cities with a consulate of a country that accepted Jewish refugees, and there was a prominent Jewish congregation in Hamburg. ${ }^{145}$

On 1 April 1937, Else became the supervisor in the laboratory of the Jewish hospital in Hamburg. ${ }^{146}$ In the following years the hospital had many problems, with staff members leaving the country and financial problems making the situation worse. There were not enough patients because it was forbidden for non-Jewish people to consult Jewish physicians. ${ }^{147}$ Else Hirschberg was responsible for the laboratory's chemical examinations. She also taught practical and theoretical physiological chemistry. ${ }^{148}$ But she was trying to find a possibility to leave the country, together with her sisters. From her correspondence with William A. Noyes (1857-1941), it is known that she wanted to explore the possibility of a non-quota immigration, independent from the regular quota. ${ }^{149}$ In 1924, Noyes had been in Rostock to attend the conference of the German Association of Chemists (Deutscher Chemikerverein), and from that time on, Else Hirschberg was in contact with him. Noyes also included the well-known chemist Max Bergmann (1886-1944) in his efforts to help Else. Bergmann had already emigrated in 1934, and obtained a position at the Rockefeller Institute in New York. But it was difficult for Noyes and Bergmann to find a job for Else because of reservations against refugees. Else suggested establishing a diagnostic laboratory alongside teaching. But this did not fit into the US educational system. Laboratory assistants were educated at colleges or universities, not in private laboratories. In his final letter on 11 November 1939, Noyes informed Else that he had sent affidavits for her, Hertha and Margot. ${ }^{150}$ The affidavits could have made immigration to the USA possible, but it seems that the Hirschberg sisters never received them.

\section{Deportation and the loss of the family}

Else, Hertha and Margot Hirschberg did not find a way of leaving Nazi Germany. Else, along with her youngest sister Margot, was deported from Hamburg to Auschwitz on 11 July $1942 .{ }^{151}$ It is not known whether they died on the way or if they were murdered in Auschwitz. ${ }^{152}$ The Stolperstein commemorating Else's death is shown in Figure 14. 


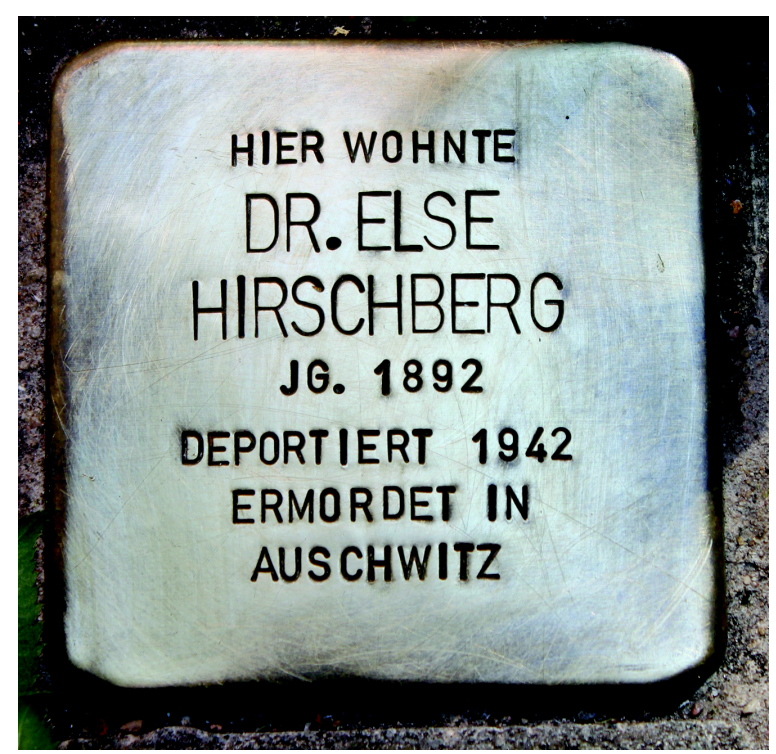

Figure 14. The Stolperstein commemorating the death of Else Hirschberg (1892-1942) (1) during the Shoah. ${ }^{153}$

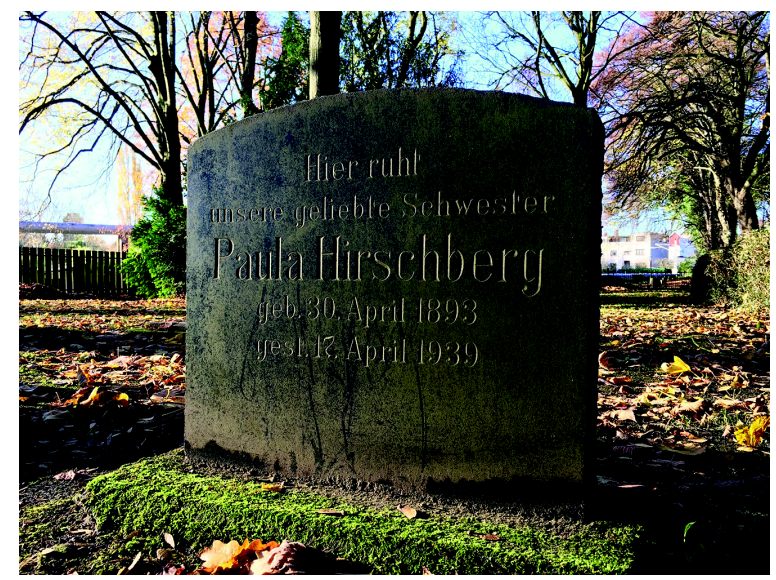

Figure 15. The gravestone of Paula Hirschberg (1893-1939) (1a) at the Jewish cemetery in Rostock. ${ }^{158}$

Else's sister Hertha worked at a home for the profoundly deaf in Berlin-Pankow which was relocated to Berlin-Weißensee in $1940 .{ }^{154}$ All the inhabitants of the home were deported with the second transport of older Jewish people to Theresienstadt concentration camp on 14 September $1942 .{ }^{155}$ Hertha Hirschberg died in Theresienstadt on 23 June $1943 .{ }^{156}$

Else's sister Paula died unmarried, like all of the four Hirschberg sisters, without any descendants, on 17 April 1939 in Leipzig, Saxony. ${ }^{157}$ The Hirschberg-Kroner family branch was thus completely extinguished during the Shoah. She is buried at the Jewish cemetery in Rostock and a picture of her gravestone can be seen in Figure 15.

\section{Conclusion}

By researching and evaluating digitised sources which have only become available in the last decade, it has been possible to rediscover the private and professional life of the first female graduate at Rostock University, Else Hirschberg, who was of the Jewish faith. Not only has her life been traced in detail, but her maternal and paternal lineage for more than three generations has been successfully established. Furthermore, a detailed picture has been drawn of the lives of her uncles and aunts. Modified German laws regarding civil registers mean that it is now possible not only to selectively trace individuals of special interest, but also whole families' fates, especially those who were murdered in the Shoah. 
Else Hirschberg worked in several disciplines and produced many and various scientific publications. Although we have not been entirely successful in identifying the circumstances which led to her decision to study chemistry or come to Rostock, an impressive picture of her scientific efforts has been drawn. Furthermore, additional information about the network that she used in her attempts to emigrate from Germany has been discovered. We believe that the rediscovery of Else Hirschberg's personal and professional life, as outlined in this article, demonstrates an exemplary case study that can be followed in future investigations of Jewish fates, especially those of German origin.

\section{Acknowledgements}

The authors thank the following people for providing information, hints and invaluable support to make this publication possible (in alphabetical order): Meike Bach (Landesarchiv Schleswig-Holstein, Schleswig), Haviv Ben-David (Israel), Björn Berghausen (Berlin-Brandenburgisches Wirtschaftsarchiv e. V., Berlin), Franziska Bogdanov (Jewish Museum Archives, Berlin), Thomas Breitfeld (Geheimes Staatsarchiv Preussischer Kulturbesitz, Berlin), Jan Cölln (Universität Rostock), Silvio Erdmann (Universitätsarchiv Rostock), Ulrike Gierens (Deutsche Bahn, Historische Sammlungen, Berlin), Petra Grams (Deutsche Gesellschaft für das Badewesen e. V. Essen), Sabine Hank (Centrum Judaicum Archives, Berlin), Margit Hartleb (Universitätsarchiv Jena), Angela Hartwig (Universitätsarchiv Rostock), Stefanie Haupt (Jewish Museum Archives, Berlin), Peter Hess (Stolpersteine Hamburg), Claudia Hinze (Stadtarchiv Leipzig), Gosia Hołowaty (Wrocław), Tomasz Jamróg (Świdnica), Jascha Lina Jennrich (Max-Samuel-Haus, Rostock), Harro Jenss (Worpswede), Steffi Katschke (Max-Samuel-Haus, Rostock), Silvija Kavcic (Koordinierungsstelle Stolpersteine Berlin), Bettina Kleinschmidt (Universitätsarchiv Rostock), Gabriele Knopf (Amt für Statistik Berlin-Brandenburg, Berlin), Klaudia Krenn (Israelistische Religionsgemeinde Leipzig), Thomas Kuczynski (Berlin), Kerstin Kühner (Universitätsmedizin, Universität Rostock), Hans-Uwe Lammel (Universitätsmedizin, Universität Rostock), Peter Langer (Institut für Chemie, Universität Rostock), Sydney J. Levine (West Hollywood), Hans H. Lembke (Berlin), Susi-Hilde Michael (Universität Rostock), Ulrike Möhlenbeck (Historisches Archiv, Akademie der Künste Berlin), Katja Neubauer (Rostock), Aleksandra Pawliczek (Archiv der Universitätsbibliothek der Humboldt-Universität Berlin), Martin Rösel (Universität Rostock), Karsten Schröder (Archiv der Hansestadt Rostock), Claudia Siegmund (Berlin), Jürgen Sielemann (Hamburg), Jennifer Strunk (LIKAT Rostock), Samira Teuteberg (University of Sussex), Judith Venus-Peppel (Rostock), Annette Vogt (Max-Planck-Institut für Wissenschaftsgeschichte, Berlin), Barbara Welker (Centrum Judaicum Archives, Berlin), Renata Wilkoszewska-Krakowska (Muzeum Sztuki Cmentarnej, Wrocław).

\section{Citation information}

Cite this article as: Peppel, Tim and Boeck, Gisela (2018) Else Hirschberg (1892-1942): the rediscovery of the private and professional life of the first female chemistry graduate at Rostock University in a digitised world. Journal of Genealogy and Family History. 2(1). pp.1-19 http://dx.doi.org/ http://dx.doi.org/10.24240/23992964.2017.1234512

\section{References}

1. Images: Photograph. August Michaelis and staff. c.1903. Rostock. Unknown photographer. Institute of Chemistry, Rostock University, Rostock, Germany.

2. Plett, Konstanze and Berghahn, Sabine. (2000) '100 Jahre BGB: Das Familienrecht als die (un)heimliche Verfassung'. In: Dickmann, E. and Schöck-Quineros, E., eds. Barrieren und Karrieren: die Anfänge des Frauenstudiums in Deutschland. Berlin: Trafo Verlag Weist. pp. 363-382.

3. Vogt, Annette. (2011) 'Wissenschaftlerinnen in Deutschland (1895-1945) im internationalen Vergleich'. In: Boeck, G. and Lammel, H.-U., eds. Frauen in der Wissenschaft. Rostocker Studien zur Universitätsgeschichte 16. Rostock: Universitätsdruckerei. pp. 143-172.

4. Kirchhoff, Arthur, ed. (1897) Die akademische Frau. Gutachten hervorragender Universitätsprofessoren, Frauenlehrer und Schriftsteller über die Befähigung der Frau zum wissenschaftlichen Studium und Berufe. Berlin: Steinitz.

5. Universität Rostock. Disziplinarvorschriften für die Studierenden der Universität Rostock, 7. Abschnitt: Vom Frauenstudium, §57, Universitätsarchiv Rostock (UAR), Rostock, Germany.

6. Johnson, Jeffrey A. (1998) German women in chemistry, 1895-1925 (Part I). NTM International Journal of History \& Ethics of Natural Sciences, Technology \& Medicine. 6.. pp. 2-3.

7. Verband der Laboratoriums-Vorstände an deutschen Hochschulen, ed. (1899) Berichte des Verbandes der Laboratoriums-Vorstände an deutschen Hochschulen. (2). p. 12.

8. Verband der Laboratoriums-Vorstände an deutschen Hochschulen, ed. (1902) Berichte des Verbandes der Laboratoriums-Vorstände an deutschen Hochschulen. (4) p. 70.
9. Tollmien, Cordula. (1997) 'Zwei erste Promotionen: die Mathematikerin Sofja Kowalewskaja und die Chemikerin Julia Lermontowa'. In: Tobies, R., ed. Aller Männerkultur zum Trotz. Frauen in Mathematik und Naturwissenschaften. Frankfurt/ Main: Campus. pp. 83-129.

10. Roussanova, Elena. (2003) Julia Lermontowa (1846-1919): die erste promovierte Chemikerin. Norderstedt: Books on Demand.

11. Rostock University. Matrikelportal. http://purl.uni-rostock.de/matrikel/200012383.

12. Verband der Laboratoriums-Vorstände an deutschen Hochschulen, ed. (1914) Berichte des Verbandes der Laboratoriums-Vorstände an deutschen Hochschulen. (17). p. 33.

13. Bundesministerium der Justiz und für Verbraucherschutz. Personenstandsgesetz (PStG). https://www.gesetze-im-internet.de/pstg/BJNR012210007.html.

14. Births (CR) Germany. Berlin. 11 February 1892. HIRSCHBERG, Else Mathilde Erna. Civil Registry Office (Standesamt) Berlin IVa, register of births (Geburtenregister) No. 203/ 1892. Collection: Berlin, Germany, Births, 1874-1899. http://www.ancestry.com.

15. Marriages (CR) Germany. Berlin. 10 April 1888. HIRSCHBERG, Louis Michael and KRONER, Aurelie. Civil Registry Office Breslau I, register of marriages (Heiratsregister) No. 380/1888. Żydowski Instytut Historyczny im. Emanuela Ringelbuma (ŻlH), 106/ 327, Oels, Heiratsurkunde Louis Michael Hirschberg (Berlin) und Aurelie Kroner (Breslau) 1888

16. Births (CR) Germany. Berlin. 30 April 1893. HIRSCHBERG, Paula Gertrud. Civil Registry Office Berlin IVa, register of births No. 487/1893. Collection: Berlin, Germany, Births, 1874-1899. http://www.ancestry.com.

17. Births (CR) Germany. Berlin. 10 January 1896. HIRSCHBERG, Bertha Hertha. Civil Registry Office Berlin IVa, register of births No. 119/1896. Collection: Berlin, Germany, Births, 1874-1899. http://www.ancestry.com.

18. Births (CR) Germany. Berlin. 10 March 1900. HIRSCHBERG, Margot Emilie. Civil Registry Office Berlin Xlla, register of births No. 663/1900. Landesarchiv Berlin. P Rep. 811, 601, Namensverzeichnis zum Geburtenregister 1900. http://www.con tent.landesarchiv-berlin.de/labsa/pdf/P_Rep_811_0601.pdf.

19. Testamentary records. Germany. 11 May 1903. KRONER, Frommuth. Will. Transcript. Collection: Gerda Sainer Collection. University of Sussex Library, SxMs170/3/0/2 (Kroner Birth Death \& Marriage Certificates II), Sussex, England.

20. Directories. Germany. (1901) Adreßbuch der Haupt- und Residenzstadt Königsberg in Preußen und seiner Vororte für 1901. Königsberg: Hartung. p. 230. http://digital.ub. uni-duesseldorf.de/ihd/periodical/structure/4703695.

21. Directories. Germany. Rostocker Adress-Buch für $1908,51^{\text {st }}$ ed. p. 133. Rostock: Verlag Carl Boldt. http://www.ancestry.com.

22. Wikipedia. Liste der Baudenkmale in Rostock. [List of monuments in Rostock.] https://de.wikipedia.org/wiki/Liste_der_Baudenkmale_in_Rostock\#S.

23. Peppel, Tim. Hirschberg-Kroner-Family Tree (private tree including 1000 individuals). https://www.ancestry.com/family-tree/tree/85069029/.

24. Births (PR) Germany. Königsberg. 6 November 1857. HIRSCHBERG, Ludwig. Register of Jews. Collection: Germany, Lutheran Baptisms, Marriages, and Burials, 15191969. http://www.ancestry.com.

25. Deaths (CR) Germany. Königsberg. 7 February 1920. HIRSCHBERG, Ludwig. Collection: Eastern Prussian Provinces, Germany [Poland], Selected Civil Vitals, 1874-1945. http://www.ancestry.com.

26. Marriages, Germany. Königsberg. 22 February 1856. HIRSCHBERG, Moritz and THEODOR, Bertha. Collection: Heiratsbeglaubigungen 1852-1858. Beglaubigungsakten der Juden, 1837-1927. Königsberg (Ostpreußen). Stadtgericht, Genealogical Society of Utah, 1962. Film 491518. https://family search.org/search/film/007951711? cat=264975.

27. Births, Germany. Königsberg. 8 March 1859. HIRSCHBERG, Ernst. Collection: Geburtsbeglaubigungen 1847-1852, 1859. Beglaubigungsakten der Juden, 1837 1927. Königsberg (Ostpreußen). Stadtgericht, Genealogical Society of Utah, 1962. Film 475875. https://familysearch.org/search/film/007951691?cat=264975.

28. Births, Germany. Königsberg. 21 November 1860. HIRSCHBERG, Paul. Collection: Geburtsbeglaubigungen 1860-1861, 1863-1865. Beglaubigungsakten der Juden, 1837-1927. Königsberg (Ostpreußen). Stadtgericht, Genealogical Society of Utah, 1962. Film 475876. https://familysearch.org/search/film/ 007951692 ? cat $=264975$. 
29. Births (PR) Germany. Königsberg. 4 September 1862. HIRSCHBERG, Robert. Register of Jews. Collection: Germany, Lutheran Baptisms, Marriages, and Burials, 15191969. http://www.ancestry.com.

30. Births, Germany. Königsberg. 18 October 1864. HIRSCHBERG, Flora Rahel Martha. Collection: Geburtsbeglaubigungen 1860-1861, 1863-1865. Beglaubigungsakten der Juden, 1837-1927. Königsberg (Ostpreußen). Stadtgericht, Genealogical Society of Utah, 1962. Film 475876. https://familysearch.org/search/film/ 007951692 ? cat $=264975$

31. Marriages (PR) Germany. Schwerin, Mecklenburg-Schwerin. 15 November 1892 HIRSCHBERG, Ernst and MÜLLER, Johanna Louise Margarethe. Collection: Mecklenburg, Germany, Parish Register Transcripts, 1740-1918. http://www.ances try.com.

32. Births (CR) Germany. Berlin. 30 May 1893. HIRSCHBERG, August Paul. Collection: Berlin, Germany, Births, 1874-1899. http://www.ancestry.com.

33. Deaths. (CR) Germany. Berlin. 5 June 1893. HIRSCHBERG, August Paul. Collection: Berlin, Germany, Deaths, 1874-1920. http://www.ancestry.com.

34. Births (CR) Germany. Berlin. 14 September 1897. HIRSCHBERG, Bertha Louis Gertrud. Collection: Berlin, Germany, Births, 1874-1899. http://www.ancestry.com.

35. Births (CR) Germany. Berlin. 6 August 1898. HIRSCHBERG, Karl Theodor Paul. Collection: Berlin, Germany, Births, 1874-1899. http://www.ancestry.com.

36. Casualty list (Germany). Charlottenburg. 15 June 1918. HIRSCHBERG, Paul. Verlustlisten 1. Weltkrieg, Seite 24308. http://des.genealogy.net/search/show/ 8345382.

37. Casualty list (Germany). 15 June 1918. HIRSCHBERG, Paul. Verlustliste: InfanterieRegiment von Lützow (1. Rheinisches) Nr. 25. http://www.denkmalprojekt.org/ 2008/vl_ir_luetzow_1_rhein_25_wk1_5komp.htm.

38. Silbergleit, Heinrich, ed. (1905) Statistisches Jahrbuch der Stadt Berlin. $30^{\text {th }}$ ed. Berlin: L. Simion. p. iii.

39. Hirschberg, Ernst. (1882) Der Arbeiter-Versicherungszwang mit besondere Berücksichtigung der Unfallversicherung. Diss. Phil. Fak. Albertus-Universität Königsberg i. Pr. Königsberg: Hartungsche Buchdruckerei.

40. Silbergleit, Heinrich. (1912) Das Statistische Amt der Stadt Berlin 1862-1912. Berlin: Grunert.

41. Deaths (CR) Germany. Berlin. 22 June 1906. HIRSCHBERG, Ernst. Collection: Berlin, Germany, Deaths, 1874-1920. http://www.ancestry.com.

42. Census. 1919. Germany. Schwerin, Mecklenburg-Schwerin. Landeshauptarchiv Schwerin. 5.12-3/20 Statistisches Landesamt (1851-1945). Microfilm reels: G654G871. http://www.ancestry.com.

43. Marriages (CR) Germany. Karlsruhe. 6 July 1916. MÜNZ, Erwin and HIRSCHBERG, Gertrud. Collection: Karlsruhe, Germany, Marriages, 1870-1921. http://www.ances try.com.

44. Baptisms (PR) Germany. Villingen, Baden. 2 August 1882. (Birth: 27 June 1882) MÜNZ, Erwin. Collection: Baden, Germany, Lutheran Baptisms, Marriages, and Burials, 1502-1985. http://www.ancestry.com.

45. Deaths (CR) Germany. Königsberg. 17 September 1941. (Birth: 27 March 1920) MÜNZ, Rainer. Collection: Eastern Prussian Provinces, Germany [Poland], Selected Civil Vitals, 1874-1945. http://www.ancestry.com.

46. Deaths (CR) Germany. Königsberg. 17 September 1941. MÜNZ, Rainer. Collection: Eastern Prussian Provinces, Germany [Poland], Selected Civil Vitals, 1874-1945. http://www.ancestry.com

47. Stolzmann, Hans. (1954) Unsere ostpreussischen Kleinbahnen. 3. Fortsetzung und Schluß. Das Ostpreußenblatt. 02 October. p. 11. http://archiv.preussische-allge meine.de/1954/1954_10_02_40.pdf.

48. Deaths (CR) Germany. Berlin. 24 February 1888. HIRSCHBERG, Paul. Collection: Berlin, Germany, Deaths, 1874-1920. http://www.ancestry.com.

49. Marriages (CR) Germany. Berlin. 13 September 1894. HIRSCHBERG, Robert and CARO, Margarethe. Collection: Berlin, Germany, Marriages, 1874-1920. http:// www.ancestry.com.

50. Births (CR) Germany. Berlin. 27 June 1870. CARO, Margarethe. Collection: Berlin Germany, Marriages, 1874-1920. http://www.ancestry.com.

51. Directories. Germany. (1899) Adreßbuch der Haupt- und Residenzstadt Königsberg in Preußen und seiner Vororte für 1899, p. 211. Königsberg: Hartung. http://digital.ub. uni-duesseldorf.de/ihd/periodical/structure/4647750.

52. Deaths (CR) Germany. Königsberg. 28 October 1914. HIRSCHBERG, Margarethe Collection: Eastern Prussian Provinces, Germany [Poland], Selected Civil Vitals, 1874-1945. http://www.ancestry.com.

53. Deaths (CR) Germany. Königsberg. 7 February 1920. HIRSCHBERG, Ludwig Collection: Eastern Prussian Provinces, Germany [Poland], Selected Civil Vitals, 1874-1945. http://www.ancestry.com.
54. Marriages (CR) Germany. Berlin. 26 July 1890. WEGER, Felix Victor Heinrich and HIRSCHBERG, Flora. Collection: Berlin, Germany, Marriages, 1874-1920. http://www. ancestry.com.

55. Marriages (CR) Germany. Berlin. 26 July 1890. WEGER, Felix Victor Heinrich and HIRSCHBERG, Flora. Collection: Berlin, Germany, Marriages, 1874-1920. http://www. ancestry.com.

56. Baptisms (PR) Germany. Königsberg. 10 June 1860. WEGER, Felix Victor Heinrich. No. 66/1860. Collection: Germany, Lutheran Baptisms, Marriages, and Burials, 1500 1971. http://www.ancestry.com

57. Weger, Felix. (1883) Beiträge zur Kenntniss des specifischen Volumens flüssiger Kohlenstoffverbindungen bei ihren Siedepunkten. Diss. Phil. Fak. Albertus-Universität Königsberg i. Pr. Königsberg: Hartungsche Buchdruckerei.

58. Deaths (CR) Germany. Berlin. 17 February 1903. WEGER, Felix. No. 244/1903. Collection: Berlin, Germany, Deaths, 1874-1920. http://www.ancestry.com.

59. Births (CR) Germany. Berlin. 3 November 1893. WEGER, Otto Paul Hermann. No. 2090/1893. Collection: Berlin, Germany, Births, 1874-1899. http://www.ancestry. com.

60. Casualty list (Germany). Berlin. 30 July 1918. WEGER, Hermann. Verlustlisten 1. Weltkrieg, Seite 26450. http://des.genealogy.net/search/show/8902471.

61. Casualty list (Germany). 30 July 1918. WEGER, Hermann. Verlustliste: Luftstreitkräfte 1914-1918. http://www.denkmalprojekt.org/verlustlisten/vl_luftstreitkraefte_14-18_ wk1_w1.htm.

62. Pietsch, Thorsten. Frontflieger. Die Soldaten der Deutschen Fliegertruppe 1914-1918. http://www.frontflieger.de/3-w-f.html.

63. Bezirksamt Charlottenburg-Wilmersdorf. Spandauer Damm 62 (früher Spandauer Straße 19). https://www.berlin.de/ba-charlottenburg-wilmersdorf/ueber-denbezirk/geschichte/stolper-steine/artikel.179390.php.

64. Koordinierungsstelle Stolperstein Berlin. Stolpersteine in Berlin. Dr. Flora Weger (geb. Hirschberg). http://www.stolpersteine-berlin.de/de/biografie/3238.

65. Marriages (CR) Germany. Berlin. 10 April 1888. HIRSCHBERG, Louis Michael and KRONER, Aurelie. Civil Registry Office Breslau I, register of marriages (Heiratsregister) No. 380/1888. Żydowski Instytut Historyczny im. Emanuela Ringelbuma (ŻlH), 106/ 327, Oels, Heiratsurkunde Louis Michael Hirschberg (Berlin) und Aurelie Kroner (Breslau) 1888.

66. Testamentary records. Germany. 11 May 1903. KRONER, Frommuth. Will. Transcript. Collection: Gerda Sainer Collection. University of Sussex Library, SxMs170/3/0/2 (Kroner Birth Death \& Marriage Certificates II), Sussex, England.

67. Images: Photograph. Aurelie Kroner. c.1888. Unknown place. Unknown photographer. Collection: Gerda Sainer Collection. University of Sussex Library, SxMs170/2/1/ 14 (Kroner family). Sussex, England.

68. Images: Photograph. Aurelie Hirschberg's gravestone. 27 October 2015. Rostock Judith Venus-Peppel, photographer. Private collection of Judith Venus-Peppel. Rostock, Germany.

69. Marriages, Germany. Züllichau. 15 January 1856. KRONER, Aron and BRODY, Frommut. Register of the Jewish community Züllichau, marriage No. 1/1856. Matrikel 1813-1874, Jüdische Gemeinde Züllichau, Zentralstelle für Genealogie Leipzig, 1983. Genealogical Society of Utah. Film 1334572.

70. Marriages (CR) Germany. Berlin. 19 May 1890. (Birth: 10 June 1858). KRONER, Siegfried and MALLACHONS, Regina. No. 606/1890. Collection: Berlin, Germany, Marriages, 1874-1920. http://www.ancestry.com.

71. Marriages (CR) Germany. Berlin. 17 October 1892. (Birth: 11 May 1863). KRONER, Hugo and LEHWESS, Clara. No. 881/1892. Collection: Berlin, Germany, Marriages, 1874-1920. http://www.ancestry.com.

72. Brocke, Michael and Carlebach, Julius, eds. (2004) Biographisches Handbuch der Rabbiner. Teil 1. Die Rabbiner der Emanzipationszeit in den deutschen, böhmischen und großpolnischen Ländern 1781-1871. München: K. G. Saur. p. 550.

73. Births, Germany. Glogau. 5 July 1828. KRONER, Aron. Register of the Jewish community Glogau, register of births 1828. Matrikel 1812-1940, Jüdische Gemeinde Glogau, Bundesarchiv Koblenz, 1958. Genealogical Society of Utah. Film 1184416.

74. Brocke, Michael and Carlebach, Julius, eds. (2004) Biographisches Handbuch der Rabbiner. Teil 1. Die Rabbiner der Emanzipationszeit in den deutschen, böhmischen und großpolnischen Ländern 1781-1871. München: K. G. Saur. p. 550.

75. Friedrich-Wilhelms-Universität Berlin (Germany). KRONER, Aron. Enrolment No. 302/ 1850. Archiv der Humboldt-Universität zu Berlin. Matrikelbuch des 41. Rektorats der Friedrich-Wilhelms-Universität zu Berlin.

76. University of Jena. PhD certificate. KRONER, Aron. Gerda Sainer Collection, University of Sussex Library. SxMs170/3/1/18/19.

77. Brocke, Michael and Carlebach, Julius, eds. (2004) Biographisches Handbuch der Rabbiner. Teil 1. Die Rabbiner der Emanzipationszeit in den deutschen, böhmischen und großpolnischen Ländern 1781-1871. München: K. G. Saur. p. 550. 
78. KRONER, Julius (1831-1898), Aron Kroner's brother. Diary entries for January 1856 and April 1858. Private collection of Sydney J. Levine, West Hollywood, USA.

79. Jehler, Manfred, ed. (1998) Die Juden und die jüdischen Gemeinde Preußens in amtlichen Enquêten des Vormärz. Teil 3. München: K. G. Saur. p. 969.

80. Deaths (CR) Germany. Breslau. 19 February 1881. KRONER, Aron. CRO Breslau I, register of deaths No. 663/1881. Zivilstandsregister, 1874-1888, Standesamt Breslau 1. Archiwum Państwowe we Wrocławiu. Genealogical Society of Utah. Film 1807651.

81. Images: Photograph. Aron Kroner's gravestone. Gerda Sainer Collection, SxMs170/ 3/1/18/13, Tombstones. Centre for German-Jewish Studies, University of Sussex Library.

82. Images: Photograph. Aron Kroner's gravesite. 03 May 2016. Wrocław. Gosia Hołowaty, photographer. Private collection of Gosia Hołowaty. Wrocław, Poland.

83. Births, Germany. Züllichau. 26 April 1834. BRODY, Frommut. Register of the Jewish community Züllichau, register of births No. 1/1834. Matrikel 1813-1874, Jüdische Gemeinde Züllichau, Zentralstelle für Genealogie Leipzig, 1983. Genealogical Society of Utah. Film 1334572

84. Deaths (CR) Germany. Berlin. 2 February 1903. KRONER, Frommuth. CRO Berlin III, register of deaths No. 133/1903. Collection: Berlin, Germany, Deaths, 1874-1920. http://www.ancestry.com

85. Monumental inscriptions. Germany. Weißensee Jewish Cemetery, Berlin. Grave No. 24806, field O, section II, row 4. Centrum Judaicum Berlin. Beisetzungsbuch des Friedhofs Weißensee.

86. Marriages (CR) Germany. Berlin. 19 May 1890. KRONER, Siegfried and MALLACHOW, Regina. CRO Berlin Vl, register of marriages No. 606/1890. Collection: Berlin, Germany, Marriages, 1874-1920. http://www.ancestry.com.

87. Marriages (CR) Germany. Berlin. 19 May 1890. (Birth: 10 November 1866). KRONER Siegfried and MALLACHOW, Regina. CRO Berlin VI, register of marriages No. 606/ 1890. Collection: Berlin, Germany, Marriages, 1874-1920. http://www.ancestry.com.

88. Births (CR) Germany. Berlin. 16 April 1891. KRONER, Eveline Erna. CRO Berlin IVa, register of births No. 1537/1891. Collection: Berlin, Germany, Births, 1874-1899. http://www.ancestry.com

89. Marriages (CR) Germany. Berlin. 6 May 1913. FEDERMANN, Paul Bernard and KRONER, Eveline Erna. CRO Deutsch-Wilmersdorf, register of marriages No. 310/1913. Collection: Berlin, Germany, Marriages, 1874-1920. http://www. ancestry.com.

90. Teuteburg, S. (2016) Death of Eveline née Kroner. E-mail to Tim Peppel, 5 September.

91. Births (CR) Germany. Berlin. 20 April 1888. FEDERMANN, Paul Bernard. CRO Berlin XII, register of births No. 1298/1888. Collection: Berlin, Germany, Births, 1874-1899. http://www.ancestry.com

92. Yad, Vashem. The Central Database of Shoah Victims' Names. Paul Federmann. http://yvng.yadvashem.org/nameDetails.html?language=en\&itemld=4096710.

93. Births (CR) Germany. Berlin. 20 August 1894. KRONER, Alice Margarethe. CRO Berlin IVb, register of births No. 2077/1894. Collection: Berlin, Germany, Births, 1874-1899. http://www.ancestry.com

94. Information provided by Samira Teuteburg, University of Sussex, UK.

95. Deaths (CR) Germany. Berlin. 23 August 1911. KRONER, Erwin Wilhelm. CRO Charlottenburg I, register of deaths No. 522/1911. Collection: Berlin, Germany, Deaths, 1874-1920. http://www.ancestry.com.

96. Monumental inscriptions. Germany. Weißensee Jewish Cemetery, Berlin. Grave No. 39296, field Z, section II, row 14. Centrum Judaicum Berlin. Beisetzungsbuch des Friedhofs Weißensee.

97. Marriages (CR) Germany. Berlin. 17 October 1892. KRONER, Hugo and LEHWESS, Clara. CRO Berlin III, register of marriages No. 881/1892. Collection: Berlin, Germany, Marriages, 1874-1920. http://www.ancestry.com.

98. Births (CR) Germany. Berlin. 19 September 1894. KRONER, Alfred Aron. CRO Berlin IVb, register of births No. 2345/1894. Collection: Berlin, Germany, Births, 1874-1899. http://www.ancestry.com

99. US Customs Service. Passenger list for lle de France departing Le Havre for New York, 8 November 1938. KRONER, Alfred. Collection: New York, Passenger Lists, 1820-1957. http://www.ancestry.com.

100. Deaths (CR) USA. 13 January 1977. KRONER, Alfred. Collection: U.S., Social Security Death Index, 1935-2014. http://www.ancestry.com

101. Deaths (CR) USA. 15 December 1991. KRONER, Thea. Collection: U.S., Social Security Death Index, 1935-2014. http://www.ancestry.com.

102. Births (CR) Germany. Berlin. 14 December 1899. KRONER, Emil Curt. CRO Berlin Ill, register of births No. 1472/1899. Collection: Berlin, Germany, Births, 1874-1899. http://www.ancestry.com

103. US Customs Service. Passenger list for Bremen departing Bremen for New York, 9 July 1936. KRONER, Emil. Collection: New York, Passenger Lists, 1820-1957. http:// www.ancestry.com
104. Deaths (CR) USA. 17 February 1988. KRONER, Emil C. Collection: U.S., Social Security Death Index, 1935-2014. http://www.ancestry.com.

105. United States Holocaust Memorial Museum. Oral history interview with Rolf Hirschberg. https://collections.ushmm.org/search/catalog/irn504930.

106. US Customs Service. Passenger list for Normandie departing Le Havre for New York, 17 December 1938. KRONER, Hugo. Collection: New York, Passenger Lists, 1820 1957. http://www.ancestry.com

107. Deaths (CR) USA. Manhattan, New York. 21 March 1939. KRONER, Hugo. Collection: New York, New York, Death Index, 1862-1948. http://www.ancestry.com.

108. Images: Photograph. Hugo Kroner. Gerda Sainer Collection. University of Sussex Library, SxMs170/2/1/14 (Kroner family). Centre for German-Jewish Studies, University of Sussex

109. Directories. Germany. (1885) Adreß- und Geschäfts-Handbuch der königlichen Hauptund Residenzstadt Breslau für das Jahr 1885. Breslau: G. Morgenstern. p. 241. https:// www.sbc.org.pl/dlibra/show-content/publication/edition/33894?id=33894.

110. Berliner Tageblatt und Handels-Zeitung. (1924) 40jähriges Geschäftsjubiläum. Berliner Tageblatt und Handels-Zeitung. Morgen-Ausgabe. 30 March. p. 6. http://zefys.staats bibliothek-berlin.de/kalender/auswahl/date/1924-03-30/.

111. Zentral- und Landesbibliothek Berlin. Berliner Adressbücher der Jahre 1799 bis 1943. https://www.zlb.de/besondere-angebote/berliner-adressbuecher.html.

112. Siegfried KRONER references. Gerda Sainer Collection. SxMs170_3_1_23. University of Sussex Library.

113. Deaths (CR) Germany. Berlin. 7 March 1908. KRONER, Regina. CRO Berlin III, register of deaths No. 266/1908. Collection: Berlin, Germany, Deaths, 1874-1920. http:// www.ancestry.com.

114. Deaths (CR) Germany. Berlin. 21 November 1913. KRONER, Siegfried. CRO Berlin IX, register of deaths No. 1830/1913. Collection: Berlin, Germany, Deaths, 1874-1920. http://www.ancestry.com.

115. Monumental inscriptions. Germany. Weißensee Jewish Cemetery, Berlin. 21 November 1913. KRONER, Siegfried. Grave No. 43543, field U, section I, row 2 Centrum Judaicum Berlin. Beisetzungsbuch des Friedhofs Weißensee.

116. Monumental inscriptions. Germany. Weißensee Jewish Cemetery, Berlin. 7 March 1908. KRONER, Regina. Grave No. 33158, field U, section I, row 2. Centrum Judaicum Berlin. Beisetzungsbuch des Friedhofs Weißensee.

117. Landesarchiv Berlin. A Rep. 342-02 - Amtsgericht Charlottenburg - Handelsregister 1900 - 1937 Ifd. Nr.: 39102, Registratursignatur: HRA 952, 01. Handelsregister A (HRA), Gebrüder Kroner, chemische Fabrik.

118. Landesarchiv Berlin. KRONER, Emil. B Rep. 025 (Knu-L) - Wiedergutmachungsämter von Berlin (Buchstabengruppe Knu-L) 1951, Registratursignatur: 52 WGA 1164/51; 05. Geschäftsstelle 5: Verfahren Alfred Kroner, 4 Ascot Ridge, Great Neck, Long Island, NY, USA, gegen Pfeilringwerke A.G. and Verfahren Emil Kroner, 245 W 74th Str., New York City, gegen Pfeilringwerke AG.

119. Landesarchiv Berlin. KRONER brothers. A Rep. 342-02 - Amtsgericht Charlottenburg - Handelsregister 1900 - 1937 Ifd. Nr.: 39102, Registratursignatur: HRA 952, 01. Handelsregister A (HRA), Gebrüder Kroner, chemische Fabrik.

120. Landesarchiv Berlin. KRONER, Alfred. B Rep. 025 (Knu-L) - Wiedergutmachungsämter von Berlin (Buchstabengruppe Knu-L) 1951, Registratursignatur: 52 WGA 1164/51; 05. Geschäftsstelle 5: Verfahren Alfred Kroner, 4 Ascot Ridge, Great Neck, Long Island, NY, USA, gegen Pfeilringwerke A.G. and Verfahren Emil Kroner, 245 W 74th Str., New York City, gegen Pfeilringwerke AG.

121. Veit, Moritz. (1847) Gesetzsammlung für die Königlich-Preussischen Staaten. Berlin: Decker, 1810-1813, No. 5 (11 $1^{\text {th }}$ March 1812). Leipzig: Brockhaus. http://sammlungen. ub.uni-frankfurt.de/freimann/content/pageview/96816.

122. Name certificate of Lewin Gedalge Kroner. Gerda Sainer Collection, SxMs170/3/1/ 18/10, University of Sussex Library.

123. Schultz, Franz. (1902) Geschichte des Kreises Deutsch-Krone. Deutsch-Krone: Garms.

124. Grünwald, Moritz. (1881) Zur Geschichte der jüdischen Gemeinde Dyhernfurth Breslau: Selbstverlag. p. 35, fn 2

125. Preußische Akademie der Künste, PrAdK 0415, 13.01. Immatrikulation, freier Unterricht. Alphabetisch Nahmen Verzeichniß. Theilnehmer an den Unterricht bey der Königl: Academie der Künste; im Jahr 1814/15 vom Aprill 1814. bis dahin 1815. https://archiv.adk.de/objekt/2307313

126. Images: Photograph. Chaim Kroner's gravesite. 1909. Dyhernfurth. Unknown photographer. Private collection of Sydney J. Levine, West Hollywood, USA.

127. Universitätsarchiv Rostock. HIRSCHBERG, Else. Verzeichnis der Behörden, Lehrer, Beamten, Institute und Studierenden der Universität Rostock, Wintersemester 1908/09 (1908): 41; Sommersemester 1909 (1909): 46; Wintersemester 1909/10 (1909): 45; Sommersemester 1910 (1910): 47; Wintersemester 1910/11 (1910): 47 Wintersemester 1911/12 (1911): 48; Sommersemester 1912 (1912): 51; Wintersemester 1912/13 (1912): 49 https://web10.ub.uni-rostock.de/wiki/Projekte: Digitalisierung_Vorlesungsverzeichnisse. 
128. Hirschberg, Else. (1928) Beiträge zur Kenntnis der Pharmokologie [sic!] von Convallaria majalis. Diss. Phil. Fak. Universität Rostock. Rostock: Buchdruckerei Richard Beckmann.

129. Verband der Laboratoriums-Vorstände an deutschen Hochschulen. (1914) Berichte des Verbandes der Laboratoriums-Vorstände an deutschen Hochschulen. (16). p. 33.

130. Universitätsarchiv Rostock. HIRSCHBERG, Else. Promotionsakte Else Hirschberg. UAR Rostock, Germany.

131. Hirschberg, Else. (1913) Die quantitative Bestimmung von geringen Mengen Traubenzucker im Harne mittels der Betrandschen Methode. Hoppe-Seyler's Zeitschrift für physiologische Chemie. 86. pp. 484-493.

132. Hirschberg, Else. (1917) 'Beiträge zur Kenntnis der Pharmakologie des Maiblümchens.' In: Kobert, R., ed. Neue Beiträge zur Kenntnis der Saponinsubstanzen für Naturforscher, Aerzte, Apotheker, Medizinalbeamte II. Stuttgart: Friedrich Enke. pp. 56-137.

133. Else Hirschberg. (1928) Beiträge zur Kenntnis der Pharmokologie [sic!] von Convallaria majalis. Diss. Phil. Fak. Universität Rostock. Rostock: Buchdruckerei Richard Beckmann. Appendix CV.

134. American Philosophical Society. Mss. B. B445 Max Bergmann Papers, Hirschberg, Else, Box 9, Folder 25. Letter from Professor Neisser, dated 14 June 1938. Philadelphia, USA.

135. American Philosophical Society. Mss. B. B445 Max Bergmann Papers, Hirschberg, Else, Box 9, Folder 25. Letter from chemical factory of Dr. Brunnengräber and the dairy Wienke. Philadelphia, USA.

136. Kaufkraftvergleich. http://fredriks.de/hvv/kaufkraft_calc.php.

137. Universitätsarchiv Rostock. HIRSCHBERG, Else. Personalakte Else Hirschberg. UAR Rostock, Germany.

138. Benecke, Otto, ed. (1927) Studium ohne Reifezeugnis in Preußen. $3^{\text {rd }}$ ed., Berlin: Weidmannsche Buchhandlung.

139. Geheimes Staatsarchiv, Preußischer Kulturbesitz. I. HA, Rep. 76 Kultusministerium Va, Sekt 1, Tit. VIII, Nr. 81a Bd. 2, Prüfungsstelle für die Zulassung zum Universitätsstudium ohne Reifezeugnis Nr. A 976. Letter dated 29 October 1927. Berlin, Germany.

140. Universitätsarchiv Rostock. HIRSCHBERG, Else. Promotionsakte Else Hirschberg.

141. Universität Rostock. HIRSCHBERG, Else. Matrikelportal - Immatrikulation von Else Hirschberg. http://purl.uni-rostock.de/matrikel/200024018.

142. Universitätsarchiv Rostock. HIRSCHBERG, Else. Personalakte Else Hirschberg.

143. Universitätsarchiv Rostock. HIRSCHBERG, Else. Personalakte Else Hirschberg.

144. Directories. Germany. (1939) Adreßbuch Hamburg 1939, $152^{\text {nd }}$ edition. Hamburg: Adreßbuch-Verlag. p. 578. http://agora.sub.uni-hamburg.de/subhh-adress/digbib/ start.

145. Paul, Gerhard. (1998) 'Nur Shanghai war noch offen'. In: Paul, G. and Gilis-Karlebakh M., eds. Menora und Hakenkreuz. Neumünster: Wacholtz Verlag. pp. 437-58.

146. American Philosophical Society. Mss. B. B445 Max Bergmann Papers, Hirschberg, Else, Folder 25. Certificate issued by Dr. M. Griesbach, dated 11 December 1938. Philadelphia, USA.

147. Jenss, Harro; Jahn, Marcus; Layer, Peter and Zornig, Carsten, eds. (2016) Israelitisches Krankenhaus in Hamburg - 175 Jahre. Berlin: Hentrich \& Hentrich.

148. American Philosophical Society. Mss. B. B445 Max Bergmann Papers, Hirschberg, Else, Folder 25. Copies of teaching references. Philadelphia, USA.

149. American Philosophical Society. Mss. B. B445 Max Bergmann Papers, Hirschberg Else, Folder 25. Letters from William A. Noyes to Else Hirschberg. Philadelphia, USA

150. American Philosophical Society. Mss. B. B445 Max Bergmann Papers, Hirschberg, Else, Folder 25. Letters from William A. Noyes to Else Hirschberg.

151. Senat der Stadt Hamburg, ed. (1965) Die jüdischen Opfer des Nationalsozialismus in Hamburg. Hamburg: Hans Christians Druckerei. p. 48.

152. Sielemann, Jürgen. (2006) Der Zielort des Hamburger Deportationstransports vom 11. Juli 1942. Zeitschrift des Vereins für Hamburgische Geschichte. 95. pp. 91-110.

153. Images: Photograph. Else Hirschberg's Stolperstein. 19 August 2016. Hamburg. Gisela Boeck, photographer. Private collection of Gisela Boeck. Rostock, Germany.

154. Wilczynski, Marianne and Lammel, Inge. (2007) 'Altersheim für die jüdischen Taubstummen'. In: Förderverein ehemaliges Jüdisches Waisenhaus Pankow e. V., Vereinigung der Verfolgten des Naziregimes, Bund der Antifaschisten, ed. Jüdische Lebenswege. Ein kulturhistorischer Streifzug durch Pankow und Niederschönhausen. Berlin: Hentrich \& Hentrich. pp. 347-50

155. Lammel, Inge. (2007) 'Zum Gedenken der ermordeten oder in den Tod getriebenen jüdischen Bürger Pankows'. In: Förderverein ehemaliges Jüdisches Waisenhaus
Pankow e. V., Vereinigung der Verfolgten des Naziregimes, Bund der Antifaschisten, ed. Jüdische Lebenswege. Ein kulturhistorischer Streifzug durch Pankow und Niederschönhausen. Berlin: Hentrich \& Hentrich. pp. 267-89.

156. holocaust.cz. Hirschberg, Hertha: Todesfallanzeige, Ghetto Theresienstadt. http:// www.holocaust.cz/de/datenbank-der-digitalisierten-dokumenten/dokument/ 96914-hirschberg-hertha-todesfallanzeige-ghetto-theresienstadt/.

157. Deaths (CR) Germany. Leipzig. 17 April 1939. HIRSCHBERG, Paula. CRO Leipzig, register of deaths No. 2318/1939. Stadtarchiv Leipzig, Germany.

158. Images: Photograph. Paula Hirschberg's gravestone. 27 October 2015. Rostock. Judith Venus-Peppel, photographer. Private collection of Judith Venus-Peppel. Rostock, Germany.

\section{Appendix A. Else Hirschberg's publications}

Hirschberg, Else and Winterstein, Hans. (1917) Über den Zuckerstoffwechsel der nervösen Zentralorgane. Hoppe-Seyler's Zeitschrift für physiologische Chemie. 100. pp. 185-202.

Hirschberg, Else and Winterstein, Hans. (1918) Über den Stickstoffumsatz der nervösen Zentralorgane. Hoppe-Seyler's Zeitschrift für physiologische Chemie. 101. pp. 212-222.

Hirschberg, Else. (1918) Der Umsatz verschiedener Zuckerarten im Stoffwechsel der nervösen Zentralorgane. Hoppe-Seyler's Zeitschrift für physiologische Chemie. 101. pp. 248-254.

Hirschberg, Else and Winterstein, Hans. (1919) Über den Umsatz von Fettsubstanzen in den nervösen Zentralorganen. Hoppe-Seyler's Zeitschrift für physiologische Chemie. 105. pp. 1-19.

Hirschberg, Else and Winterstein, Hans. (1919) Stickstoffsparende Substanzen im Stoffwechsel der nervösen Zentralorgane. Hoppe-Seyler's Zeitschrift für physiologische Chemie. 108. pp. 9-20.

Hirschberg, Else and Winterstein, Hans. (1919) Fettsparende Substanzen im Stoffwechsel der nervösen Zentralorgane. Hoppe-Seyler's Zeitschrift für physiologische Chemie. 108. pp. 21-23.

Hirschberg, Else. (1919) Die Verwertung von "Calorose" im Stoffwechsel der nervösen Zentralorgane. Hoppe-Seyler's Zeitschrift für physiologische Chemie. 108. pp. 24-26.

Hirschberg, Else and Winterstein, Hans. (1919) Über den Stoffwechsel des peripheren Nervensystems. Hoppe-Seyler's Zeitschrift für physiologische Chemie. 108. pp. 27-37. Winterstein, Hans and Hirschberg, Else. (1919) Über den Einfluß der Temperatur auf die Oberflächenspannung narkotischer Stoffe. Biochemische Zeitschrift. 100. pp. 81-83.

Winterstein, Hans and Hirschberg, Else. (1925) Über Ammoniakbildung im Nervensystem. Biochemische Zeitschrift. 156. pp. 138-149.

Winterstein, Hans and Hirschberg, Else. (1925) Über den Glykogen- und Cerebrosidstoffwechsel des Zentralnervensystems. Biochemische Zeitschrift. 159. pp. 351-369.

Winterstein, Hans and Hirschberg, Else. (1926) Neue Versuche über den Stickstoffumsatz in den Nervenzentren. Biochemische Zeitschrift. 167. pp. 401-410.

Winterstein, Hans and Hirschberg, Else. (1927) Über Löslichkeit und Verteilung des Chloroforms im Blute. Biochemische Zeitschrift. 186. pp. 172-177.

Winterstein, Hans and Hirschberg, Else. (1927) Alles- oder Nichts-Gesetz und Stoffwechsel. Pflüger's Archiv für die gesamte Physiologie des Menschen und der Tiere 216. pp. 271-280.

Winterstein, Hans and Hirschberg, Else. (1927) Über die Permeabilität von Muskelmembranen. Pflüger's Archiv für die gesamte Physiologie des Menschen und der Tiere. 217. pp. 216-220.

Fröhlich, Friedrich W.; Hirschberg, Else and Monjé, Manfred. (1928) Der zeitliche Verlauf der Aktionsströme vom Wirbeltierauge. Zeitschrift für Biologie. 87 pp. 517-526.

Hirschberg, Else. (1930) Ueber die Abhängigkeit der Empfindungszeit des Gesichtssinnes vom zeitlichen Verlauf des Reizanstieges. Zeitschrift für Biologie. 90. pp. 81-96.

Hirschberg, Else. (1931) Über nervöse Hemmungen. Zeitschrift für Biologie. 91. pp.

117-125

Hirschberg, Else. (1932) Schwellenbestimmungen an antagonistischen NervMuskelpräparaten mit Kondensatorentladungen verschiedener Frequenz. Zeitschrift für Biologie. 92. pp. 241-253.

Hirschberg, Else. (1932) Weitere Untersuchungen über die Umkehr des RitterRollettschen Phänomens. Zeitschrift für Biologie. 97. pp. 505-512. 


\section{ABOUT THE AUTHORS}

Tim Peppel (b. 1983) is a professional chemist currently working at the Leibniz Institute for Catalysis in the field of heterogeneous photocatalysis. He has been interested in genealogy for more than fifteen years and started scientific research on the history of Rostock University, and in particular on the family history of the first chemists in Rostock, in collaboration with Gisela Boeck in 2014. He is the author of a variety of scientific publications in the field of chemistry and this is his first publication related directly to family history research on a chemist.

Email: tim.peppel@catalysis.de

https://orcid.org/0000-0002-7814-7235

Gisela Boeck (b. 1954) is a professional chemist working for many years in the field of the history of chemistry. Since 2003 she has been spokesperson of the research group on the history of sciences at Rostock University (Arbeitskreis "Rostocker Universitäts- und Wissenschaftsgeschichte"). Since 2009 she has been also deputy of the German Chemical Society (GDCh) at the Working Party on the History of Chemistry of the European Association for Chemistry and Molecular Science (EuCheMS). Gisela Boeck is the author of many publications especially in the field of the history of chemistry, the history of chemical education, and the popularisation of chemistry in the nineteenth century. She is also the author of several chemistry textbooks as well as the editor of many publications on the history of Rostock University.

Email: gisela.boeck@uni-rostock.de

Both authors contributed equally to this publication. Please contact Tim Peppel with any queries. 